Check for updates

Cite this: Phys. Chem. Chem. Phys., 2019, 21, 1552

Received 22nd July 2018, Accepted 5th November 2018

DOI: 10.1039/c8cp04652b

rsc.li/pccp

\section{Evaluating chemical bonding in dioxides for the development of metal-oxygen batteries: vibrational spectroscopic trends of dioxygenyls, dioxygen, superoxides and peroxides $\dagger$}

\author{
Petar M. Radjenovic and Laurence J. Hardwick (D)* \\ Dioxides (dioxygenyl $\left(\mathrm{O}_{2}{ }^{+}\right)$, dioxygen $\left(\mathrm{O}_{2}\right)$, superoxide $\left(\mathrm{O}_{2}{ }^{--}\right)$and peroxide $\left(\mathrm{O}_{2}{ }^{2-}\right)$ ) are of immense \\ biological, chemical and environmental importance. The ability to accurately detect and measure the \\ changing strength of their chemical bonding and coordination in situ or operando is extremely \\ beneficial in order to evaluate their chemical properties, this has been particularly important recently \\ in the field of metal-oxygen batteries, where understanding the reactivity of the $\mathrm{O}_{2}{ }^{\bullet-}$ intermediate is \\ crucial in the development of more stable electrolytes. Meta-analysis of the collated vibrational Raman \\ and IR spectral bands of numerous ( $>200$ ) dioxygen species was used to interpret the effect that the \\ immediate chemical environment has on the $\mathrm{O}-\mathrm{O}$ bond. Subsequently, the dioxide vibrational spectral \\ bands were empirically related directly with the bond electron density and other fundamental \\ bond properties, with surprisingly high accuracy, allowing each property to be estimated, simply, from \\ experimental spectroscopic observations. Important chemical information about the strength of secondary \\ interactions between reduced oxygen species and its chemical environment can be also elucidated which \\ provides a convenient method for determining the attractive strength an ion exerts over neighbouring \\ counter ions.
}

\section{Introduction}

Oxygen (O) is a reactive and abundant element of immense chemical, biological, and environmental importance, warranting classification as a field of study in its own right similar to organic (carbon) and inorganic (transitional metal) chemistries. ${ }^{1,2}$ Gaseous dioxygen $\left(\mathrm{O}_{2}\right)$, composed of two covalently bonded homonuclear atoms, constitutes $20.95 \%$ of Earth's atmosphere, providing an oxidising environment and thermodynamic driving force for many biological processes. Crucially, the controlled reaction of $\mathrm{O}_{2}$ in the oxidation of glucose during aerobic respiration allows life on Earth to thrive. However, living organisms must also possess kinetic barriers to slow oxidation reactions with $\mathrm{O}_{2}$ to survive. The gradual decay of these kinetic barriers to oxidation in the body is responsible for ageing. In humans, reactive oxide species (ROSs): $\mathrm{O}_{2}{ }^{\bullet-}, \mathrm{O}_{2}{ }^{2-}, \mathrm{O}^{2-}, \mathrm{HO}_{2}$, $\mathrm{H}_{2} \mathrm{O}_{2}$ and $\mathrm{OH}^{\bullet}$ are produced as by-products of normal cell processes and are used in the immune response of white blood cells. However, excessive production of ROSs adds oxidative

Stephenson Institute for Renewable Energy, Department of Chemistry, University of Liverpool, L69 7ZF, UK. E-mail: hardwick@liverpool.ac.uk $\dagger$ Electronic supplementary information (ESI) available: Tabulated data from meta-analysis. See DOI: 10.1039/c8cp04652b stress to cells causing cell and DNA damage (specifically mitochondrial DNA) which is linked to the formation of cancer cells. $^{3-5}$

Metal-oxygen $\left(\mathrm{M}-\mathrm{O}_{2}\right)$ batteries have to deal with many of the same problems faced by biological systems, such as controlling the production and side reaction rate of ROSs. In addition, dioxide ligands are prevalent in organometallic and catalysis chemistry. Therefore, the chemistry of dioxide species' $\left(\mathrm{O}_{2}{ }^{x}\right.$, where $x=-2,-1,0$ or +1$)$ has warranted detailed scientific study in multiple fields. ${ }^{1,2,6}$

$\mathrm{O}_{2}{ }^{x}$ are homonuclear molecules that possess covalent $\mathrm{O}-\mathrm{O}$ bonds and their characteristic symmetric stretching vibrations $\left(\nu_{\mathrm{O}-\mathrm{O}}\right)$ are visible spectroscopically. Examining the $\nu_{\mathrm{O}-\mathrm{O}}$ spectral band can provide valuable information about the chemical nature of the $\mathrm{O}_{2}{ }^{x}$. The oxidation state and reactivity of $\mathrm{O}_{2}{ }^{x}$, depends on the number of electrons occupying the highest occupied molecular orbital (HOMO), which are the $\pi^{*}\left(2 \mathrm{p}_{x y}\right)$ valence antibonding orbitals (Fig. 1), their spin state(s) and the $\mathrm{O}-\mathrm{O}$ bond order $\left(B_{\mathrm{O}}\right.$, defined as the number of covalent bonds, see eqn (1)). $\mathrm{O}_{2}{ }^{+}$cations possess one electron in the $\pi^{*}\left(2 \mathrm{p}_{x}\right)$ antibonding orbital and have a $B_{\mathrm{O}}$ of 2.5. $\mathrm{O}-\mathrm{O}$ bonding electrons in $\mathrm{O}_{2}{ }^{+}$cations experience high effective nuclear charge from the $\mathrm{O}$ nuclei, so have a short $\mathrm{O}-\mathrm{O}$ bond length $\left(B_{\mathrm{L}}, 1.12 \AA\right)$ and a high wavenumber $\nu_{\mathrm{O}-\mathrm{O}}\left(1876 \mathrm{~cm}^{-1}\right)$ value. ${ }^{7,8}$ From $\mathrm{O}_{2}{ }^{+}$to $\mathrm{O}_{2}{ }^{2-}$, 


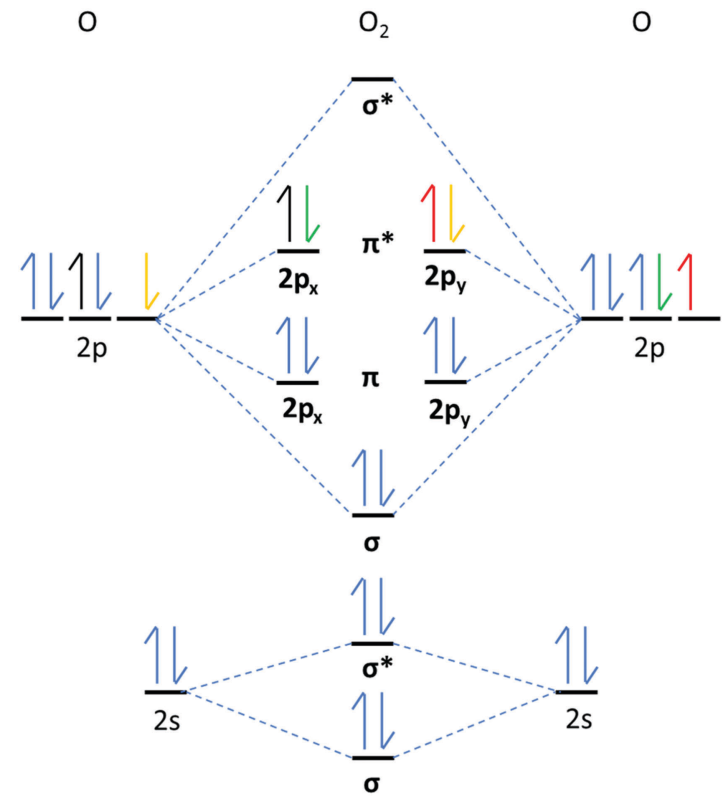

Fig. 1 Molecular orbital diagram of $\mathrm{O}_{2}{ }^{x}$ species based on filled $\pi^{\star}\left(2 p_{x y}\right)$ valence orbitals: $\mathrm{O}_{2}{ }^{+}$(black arrow only), high-energy singlet $\left({ }^{1} \Sigma_{g}^{+}\right) \mathrm{O}_{2}$ (black and orange arrows only), singlet $\left({ }^{1} \Delta_{g}\right) \mathrm{O}_{2}$ (black and green arrows only), triplet $\left({ }^{3} \Sigma_{\mathrm{g}}^{-}\right) \mathrm{O}_{2}$ (black and red arrows only), $\mathrm{O}_{2} \cdot{ }^{--}$(black, green, red arrows only) and $\mathrm{O}_{2}{ }^{2-}$ (black, green, red, orange arrows).

the $B_{\mathrm{O}}$ decreases by 0.5 for each electron added into the $\pi^{*}\left(2 \mathrm{p}_{x y}\right)$ orbital. As an electron is added to the $\pi^{*}\left(2 \mathrm{p}_{x y}\right)$ orbital, increased antibonding and Coulombic repulsion between bonding electrons cause the $\mathrm{O}-\mathrm{O} B_{\mathrm{L}}$ to increase and the $\nu_{\mathrm{O}-\mathrm{O}}$ to red-shift. $\mathrm{O}_{2}{ }^{2-}$ possesses a $B_{\mathrm{O}}$ of 1 and has the longest $\mathrm{O}-\mathrm{O}$ bond $(1.49 \AA)$ of the homonuclear dioxides with the lowest $\nu_{\mathrm{O}-\mathrm{O}}$ value $\left(\sim 743 \mathrm{~cm}^{-1}\right) .{ }^{9}$ In addition to $\mathrm{O}-\mathrm{O}$ bond lengthening and the characteristic red shifts in $\nu_{\mathrm{O}-\mathrm{O}}$ spectra, each electron transferred to $\mathrm{O}_{2}{ }^{x}$ causes a decrease in the bond force constant $\left(B_{\mathrm{k}}\right)$ and a drop in the bond dissociation enthalpy $\left(B_{\mathrm{H}}\right)$ of the $\mathrm{O}-\mathrm{O}$ bond, discussed in more detail later.

$$
B_{\mathrm{O}}=\frac{\left(q-q^{*}\right)}{2}
$$

where $B_{\mathrm{O}}=$ bond order, $q=$ number of bonding electrons, $q^{*}=$ number of antibonding electrons.

Neutral $\mathrm{O}_{2}$ contains two electrons in the $\pi^{*}\left(2 \mathrm{p}_{x y}\right)$ orbital(s) that can occupy three different spin states (Fig. 1); high-energy singlet $\left({ }^{1} \Sigma_{\mathrm{g}}^{+}\right)$, singlet $\left({ }^{1} \Delta_{\mathrm{g}}\right)$ and triplet $\left({ }^{3} \Sigma_{\mathrm{g}}^{-}\right)$. Unlike many common diatoms and organic molecules, which favour the ${ }^{1} \Delta_{\mathrm{g}}$ state, the ${ }^{3} \Sigma_{\mathrm{g}}^{-}$state is the lowest energy ground state of $\mathrm{O}_{2}$ with two electrons in degenerate orbitals with the same spin. The ${ }^{3} \Sigma_{\mathrm{g}}^{-} \mathrm{O}_{2}$ orbital structure complicates coupling with other molecules in the ${ }^{1} \Delta_{\mathrm{g}}$ state, which adds to the chemical stability of ${ }^{3} \Sigma_{\mathrm{g}}^{-} \mathrm{O}_{2}$. It is the: one-electron, two-electron or four-electron transition from ${ }^{3} \Sigma_{\mathrm{g}}^{-} \mathrm{O}_{2}$ to: $\mathrm{O}_{2}{ }^{\bullet-}, \mathrm{O}_{2}{ }^{2-}$ or $\mathrm{O}^{2-}$, respectively, and back again, that underpins the oxygen reduction and evolution reactions (ORR/OERs). For non-aqueous lithium oxygen $\left(\mathrm{Li}-\mathrm{O}_{2}\right)$ batteries, in situ surface enhanced Raman spectroscopic (SERS) studies of $\nu_{\mathrm{O}-\mathrm{O}}$ have been instrumental in showing $\mathrm{a} \mathrm{O}_{2}{ }^{\bullet-}$ intermediary reaction mechanism and the existence of lithium peroxide $\left(\mathrm{Li}_{2} \mathrm{O}_{2}\right)$ as the primary battery discharge product. ${ }^{10-12}$
Johnson et al. ${ }^{11}$ in particular highlighted the effect of solvent choice in the determination of the ORR pathway via either surface or solution route. Using SERS they showed that lowdonor number solvents, such as acetonitrile, lead to a surface reaction resulting in thin, insulating $\mathrm{Li}_{2} \mathrm{O}_{2}$ film growth. In contrast, in high-donor number solvents, such dimethyl sulfoxide resulted in preferential $\mathrm{Li}_{2} \mathrm{O}_{2}$ particle growth in solution. High donor number solvents are thereby preferable in the context of $\mathrm{Li}-\mathrm{O}_{2}$ batteries as $\mathrm{Li}_{2} \mathrm{O}_{2}$ solution growth leads to higher capacities.

Creighton et al. first reported the $\nu_{\mathrm{O}-\mathrm{O}}$ stretch of $\mathrm{O}_{2}{ }^{\bullet-}$ with Raman spectroscopy of $\mathrm{KO}_{2}$ and contaminated $\mathrm{Na}_{2} \mathrm{O}_{2}$ in $1964 .^{13}$ This was corroborated and expanded upon with other group-1 alkali-metal cation complexes $\left(\left[\mathrm{M}^{+} \cdots \mathrm{O}_{2}{ }^{\bullet-}\right]\right.$, where $\mathrm{M}=\mathrm{Li}, \mathrm{Na}$, $\mathrm{K}, \mathrm{Rb}$ or $\mathrm{Cs}$ ) in the following decade at a variety of different temperatures. ${ }^{14-21}$ Sawyer et al. synthesised and spectroscopically characterised the first $\mathrm{O}_{2}{ }^{\bullet-}$ salt with an organic cation, in 1983, by substituting $\mathrm{K}^{+}$with tetramethylammonium $\left(\mathrm{TMA}^{+}\right){ }^{22}$ $\left[\mathrm{TMA}^{+} \cdots \mathrm{O}_{2}^{\bullet-}\right]$ had a spectrum analogous to $\mathrm{KO}_{2}$, though slightly red shifted $\left(\sim 22 \mathrm{~cm}^{-1}\right) .{ }^{22}$ Since then, the $\nu_{\mathrm{O}-\mathrm{O}}$ of many $\mathrm{O}_{2}{ }^{\bullet-}$ complexes $\left[\mathrm{C}^{+} \cdots \mathrm{O}_{2}{ }^{\bullet-}\right]$ have been detected in a variety of systems and phases. Such as: solid salts, ${ }^{13,22}$ doped into other salts, ${ }^{23}$ as an organometallic complex, ${ }^{6}$ dissolved in organic solvents ${ }^{24}$ or generated electrochemically at a SERS active electrode-electrolyte interface. ${ }^{10,11,25,26}$

Understanding the reactivity and bonding environment of the $\mathrm{O}_{2}{ }^{\bullet-}$ intermediate is crucial in the development of more stable $\mathrm{M}-\mathrm{O}_{2}$ battery electrolytes and in particular, ambiguity around the existence and chemical character of the lithium superoxide $\left(\mathrm{LiO}_{2}\right)$ intermediary remains. ${ }^{27,28}$ Thus, a detailed look at the $\nu_{\mathrm{O}-\mathrm{O}}$ spectra of species produced during ORR/OERs is warranted to better understand in the reaction mechanisms in non-aqueous electrolytes in order to assist in the fundamental understanding of lithium-oxygen and in more general other $\mathrm{M}-\mathrm{O}_{2}$ batteries.

\section{Experimental}

\subsection{Calculation of ion properties}

Ionic volumes, ionic surface area, charge distributions and electrostatic potential surface distributions for a number of molecular ions were determined using a simple density functional theory (DFT, B3LYP functional, 6-31G* basis set) in Spartan 16. Ionic volumes and surface areas for atomic cations were calculated using a simple pace-filling calotte (CPK) model.

\section{Results and discussion}

\subsection{Meta-analysis of superoxide's Raman spectra}

To investigate possible trends of $\mathrm{O}_{2}^{\bullet-}$ bonding, relevant literature reports of $>50$ species were collated and examined. ${ }^{10,11,13-18,25,26,29-60}$ See Table S1 (ESI $\dagger$ ) for a catalogue of reported $\left[\mathrm{C}^{+} \cdots \mathrm{O}_{2}{ }^{\bullet-}\right]$ complexes.

Raman spectral band positions reflect molecular energy levels in a vibrating bond and are well known to be influenced by (1) the mass of the atoms in the bond, (2) the bond force constant and (3) lattice/symmetry effects. For $\left[\mathrm{C}^{+} \cdots \mathrm{O}_{2}^{\bullet-}\right]$, 
counter cations (or strongly coordinating solvents) attract $\mathrm{O}-\mathrm{O}$ bond electron density at different rates which also influences the force constant of the vibration, resulting in $\nu_{\mathrm{O}-\mathrm{O}}$ band shifts, explained further below. ${ }^{61}$

The molecular mass-to-charge ratio $\left(M_{\mathrm{r}} Q^{-1}\right.$, units: $\left.\mathrm{mol} \mathrm{g}^{-1} \mathrm{C}^{-1}\right)$ of an ion can dictate its Columbic attractive strength towards counter-ions. Generally, ions with low $M_{\mathrm{r}} Q^{-1}$ values are stronger Coulombic attractors than ions with high values. In a $\left[\mathrm{C}^{+} \cdots \mathrm{O}_{2}{ }^{\bullet-}\right]$ complex, where interactions between $\mathrm{O}_{2}{ }^{\bullet-}$ and the countercation $\left(\mathrm{C}^{+}\right)$are weak: electron density is more concentrated on the $\mathrm{O}_{2}{ }^{--}$anion, the effective nuclear charge experienced by $\mathrm{O}-\mathrm{O}$ valence bonding electrons is lower and the bond is longer than when $\mathrm{O}_{2}{ }^{\bullet-}$ is strongly coordinated. This effect is visible spectroscopically, with weakly coordinated $\mathrm{O}_{2}{ }^{\bullet-}$ complexes having lower wavenumber $\nu_{\mathrm{O}-\mathrm{O}}$ values (e.g. tetrabutylammonium $\left.\left[\mathrm{TBA}^{+} \cdots \mathrm{O}_{2}{ }^{\bullet-}\right]:<1115 \mathrm{~cm}^{-1}\right)^{10,11,25,26,60}$ and strongly coordinated $\mathrm{O}_{2}{ }^{\bullet-}$ complexes having higher $\nu_{\mathrm{O}-\mathrm{O}}$ values $\left(\right.$ e.g. $\left[\mathrm{Na}^{+} \cdots \mathrm{O}_{2}{ }^{\bullet-}\right]$ : $\left.\geq 1155 \mathrm{~cm}^{-1}\right) .{ }^{15,17,47-52,62}$ The strength of the attraction between the coordinating cation and $\mathrm{O}_{2}{ }^{\bullet-}$ effects valence bond electron density and the $\mathrm{O}-\mathrm{O}$ bond force constant, causing the observed difference in $\nu_{\mathrm{O}-\mathrm{O}}$ wavenumbers.

For monovalent $\left[\mathrm{C}^{+} \cdots \mathrm{O}_{2}{ }^{-}\right]$complexes (independent of phase), plotting reported $\nu_{\mathrm{O}-\mathrm{O}}$ values against the $M_{\mathrm{r}} Q^{-1}$ value of the coordinating cation (Fig. 2) shows an inverse trend $\left(R^{2}=0.757\right)$. In Fig. 2, two further sub-trends are apparent for: (1) single atom cations (shown in blue) and (2) molecular

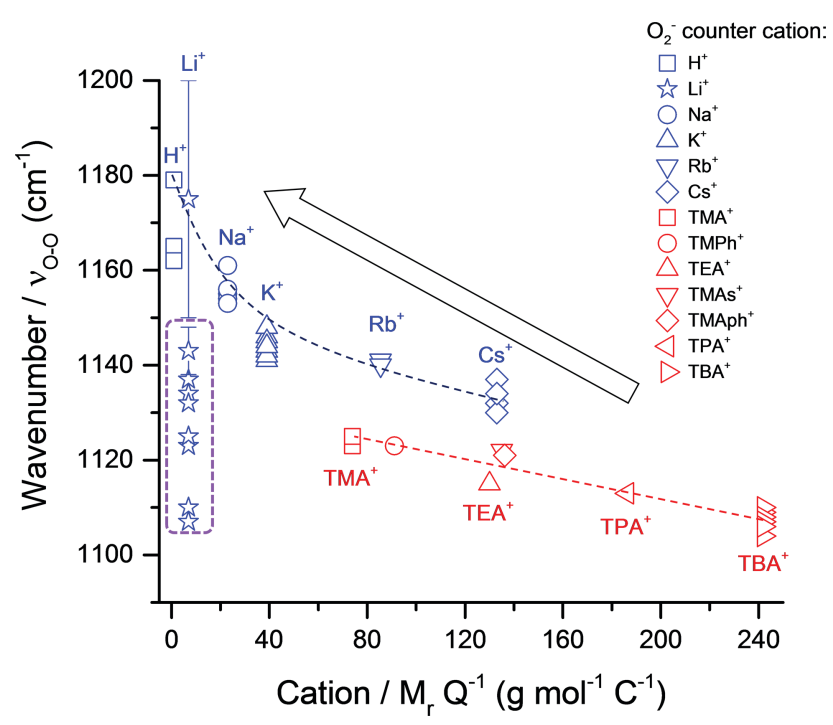

Fig. $2 \nu_{\mathrm{O}-\mathrm{O}}$ Raman bands for $\left[\mathrm{C}^{+} \ldots \mathrm{O}_{2}{ }^{--}\right]$complexes plotted against the $M_{r} Q^{-1}$ value of the coordinating cation (listed data in Table S1, ESI $\dagger$ ). An inverse trend is visible with heavier coordinating cations having lower wavenumber $\nu_{\mathrm{O}-\mathrm{O}}$ bands indicating a less energetic $\mathrm{O}_{2}{ }^{\bullet-}$ bond vibration and a 'freer' more Lewis basic species. A general fit produced $R^{2}$ values of 0.757 for the overall trend. Two sub-trends are apparent: (1) single atom and (2) molecular coordinating-cations. Lines of best fit for both trends (dashed lines) had $R^{2}$ values of 0.850 and 0.867 for single atom (blue) and molecular (red) coordinating cations, respectively. Circled bands (purple dashed line) are reports of $\mathrm{LiO}_{2}$ related species. These do not match the expected trend for $\mathrm{Li}^{+}$, discussed later. Error bar refers to broad band between $1150-1200 \mathrm{~cm}^{-1}$ reported as $\mathrm{LiO}_{2}$ by Xia et al. ${ }^{36}$ cations (shown in red). Single atom cations such as $\mathrm{Rb}^{+}$ (85.5 $\mathrm{mol} \mathrm{g}^{-1} \mathrm{C}^{-1}$ ) and $\mathrm{Cs}^{+}\left(132.9 \mathrm{~mol} \mathrm{~g}^{-1} \mathrm{C}^{-1}\right.$ ) have similar $M_{\mathrm{r}}$ values as $\mathrm{TMA}^{+}\left(74 \mathrm{~mol} \mathrm{~g}^{-1} \mathrm{C}^{-1}\right)$ and tetraethylammonium $\left(\mathrm{TEA}^{+}\right.$) (130.0 mol g ${ }^{-1} \mathrm{C}^{-1}$ ), respectively, but have higher wavenumber $\nu_{\mathrm{O}-\mathrm{O}}$ spectral bands $\left(>15 \mathrm{~cm}^{-1}\right)$. This difference in the $\nu_{\mathrm{O}-\mathrm{O}}$ spectral bands can be accounted for by considering the size difference in these cations. Single atom alkali-metal cations are spatially smaller allowing them interact more closely with $\mathrm{O}_{2}{ }^{\bullet-}$ valence bond electron density than large molecular organic cations. Therefore, as a general rule: strong $\mathrm{O}_{2}{ }^{\bullet-}$ coordination has a higher wavenumber $\nu_{\mathrm{O}-\mathrm{O}}$ spectral band.

\subsection{Ionic charge dispersion}

The immediate coordinating environments ability to interact with $\mathrm{O}_{2}^{\bullet-}$ also provides interesting information about the reactivity and basicity of $\mathrm{O}_{2}{ }^{--}$in the complex which is reflected in the $\nu_{\mathrm{O}-\mathrm{O}}$ value. From Fig. $2,\left[\mathrm{C}^{+} \cdots \mathrm{O}_{2}{ }^{--}\right]$containing high $M_{\mathrm{r}}$ cations $\left(\right.$ e.g. $\left.\mathrm{TBA}^{+}\right)$have low $\nu_{\mathrm{O}-\mathrm{O}}$ values indicative of a more ionic 'freer' $\mathrm{O}_{2}{ }^{\bullet-}$ species. In these complexes, $\mathrm{O}_{2}{ }^{\bullet-}$ is a stronger Lewis base and can be expected to more readily donate electron density. Inversely, low $M_{\mathrm{r}}$ cation containing $\left[\mathrm{C}^{+} \ldots \mathrm{O}_{2}{ }^{\bullet-}\right]$ complexes such as $\left(\mathrm{H}^{+}\right)$have stronger $\mathrm{C}^{+}$-to- $\mathrm{O}_{2}{ }^{\bullet-}$ interactions with slight covalent character, resulting in higher wavenumber $\nu_{\mathrm{O}-\mathrm{O}}$ bands indicative of a weaker Lewis base $\mathrm{O}_{2}{ }^{\bullet-}$ species. It was found that for cations coordinating $\mathrm{O}_{2}{ }^{x}$ species, the: size, mass and charge influence the strength of coordination and in turn the $\mathrm{O}-\mathrm{O}$ bond force constant which causes detectable changes in $\nu_{\mathrm{O}-\mathrm{O}}$. Thus, the physical parameters of one ion can indirectly influence the bond force constant and wavenumber of bonds present in the counterion. These values for ions can be simply quantified in terms of the $M_{\mathrm{r}}$, ionic volume $\left(i_{\mathrm{v}}\right)$ and the charge on the ion $(z)$. In $\mathrm{O}_{2}{ }^{x}$ complexes; changes in the $M_{\mathrm{r}}$ and $i_{\mathrm{v}}$ of the coordinating counterions were found to be inversely proportional to changes in $\nu_{\mathrm{O}-\mathrm{O}}$ whilst changes in the charge of the counter-ion were proportional quantified by the term. Considering the effect the size of the cation has on the $\nu_{\mathrm{O}-\mathrm{O}}$ of $\mathrm{O}_{2}{ }^{\bullet-}$ complexes, this can be quantified by either the ionic volume $\left(i_{\mathrm{v}}\right)$ or the available ionic surface area $\left(i_{\text {s.a. }}\right)$, measured in $\AA^{3}$ and $\AA^{2}$, respectively. $i_{\mathrm{v}}$ and $i_{\text {s.a. }}$ values are known for most alkali-metal cations and can be calculated computationally using simple CPK or DFT models for larger molecular cations.

The $\nu_{\mathrm{O}-\mathrm{O}}$ of a $\left[\mathrm{C}^{+} \cdots \mathrm{O}_{2}{ }^{-}\right]$complex changes proportionally with the charge $(q)$ on the cation and inversely proportionally with the molecular mass $\left(M_{\mathrm{r}}\right)$ and $i_{\mathrm{v}}$ (and $i_{\text {s.a. }}$ ) of the coordinating cation (eqn (2)). Assuming a uniform charge distribution over the ion: multiplying the $M_{\mathrm{r}} Q^{-1}$ and a spatial component $\left(i_{\mathrm{v}}\right.$ or $i_{\text {s.a. }}$ ) gives a parameter (eqn (3)), hereon named the 'ionic charge dispersion' $(\mathscr{K})$.

$$
\begin{gathered}
\nu_{\mathrm{O}-\mathrm{O}} \propto \frac{Q^{\mathrm{C}}}{M_{\mathrm{r}}^{\mathrm{C}}}, \frac{1}{i_{\mathrm{v}}^{\mathrm{C}}} \text { or } \frac{1}{i_{\text {s.a. }}^{\mathrm{C}}} \\
\mathscr{T}_{i_{\mathrm{v}}}^{\mathrm{C}}=\frac{\left(i_{\mathrm{v}}^{\mathrm{C}} M_{\mathrm{r}}^{\mathrm{C}}\right)}{Q^{\mathrm{C}}} \\
\nu_{\mathrm{O}-\mathrm{O}} \propto \frac{1}{\mathscr{W}_{i_{\mathrm{v}}^{\mathrm{C}}}^{\mathrm{C}}}
\end{gathered}
$$


where: $\nu_{\mathrm{O}-\mathrm{O}}=\mathrm{O}_{2}{ }^{\bullet-}$ stretch $\left(\mathrm{cm}^{-1}\right), M_{\mathrm{r}}^{\mathrm{C}}=$ molecular mass of coordinating cation, $Q^{\mathrm{C}}=$ charge on cation, $i_{\mathrm{v}}^{\mathrm{C}}=$ ionic volume of cation $\left(\AA^{3}\right)$.

The $\mathscr{T}$ value can be used to estimate the Coulombic attractive strength of an ion and the effect it will have on counter-ions. The Cyrillic symbol for $\check{Z}(\mathscr{T})$ is used for ionic charge dispersion, subscripts $i_{\mathrm{v}}$ and $i_{\text {s.a. }}$ denote the use of ionic volume or ionic surface area, respectively, and superscripts A and $\mathrm{C}$ denote anion and cation, respectively. $\mathscr{T}$ is an analogue of the charge density of an ion $\left(M_{\mathrm{r}} Q^{-1} i_{\mathrm{v}}{ }^{-1}\right)$. However, charge density does not account for the proportional relationship between: $M_{\mathrm{r}}, i_{\mathrm{v}}$ and the Columbic attractive strength of the ion. Thus, $\mathscr{T}$ has been derived as a simple value to describe these ionic properties. $\mathscr{T}$ is a measure the 'bulkiness' of the counterion, where, the higher the $\mathscr{T}$ value the bulkier the ion is.

Excluding outliers, plotting the reported $\nu_{\mathrm{O}-\mathrm{O}}$ values of $\left[\mathrm{C}^{+} \ldots \mathrm{O}_{2}{ }^{--}\right]$complexes from Table 1 against the calculated $\varlimsup_{i_{\mathrm{v}}}^{\mathrm{C}}$ (units: $\mathrm{mol} \mathrm{g}{ }^{-1} \AA^{3} \mathrm{C}^{-1}$ ) or $\varlimsup_{i_{\text {s.a. }}^{\mathrm{C}}}^{\mathrm{C}}$ (units: mol g ${ }^{-1} \AA^{2} \mathrm{C}^{-1}$ ) of each coordinating cation shows a clear inverse exponential relationship (Fig. 3 and Fig. S1, respectively, ESI $\dagger$ ). $Æ$ provides a much better fit than using the $M_{\mathrm{r}}^{\mathrm{C}}$ or $i_{\mathrm{v}}^{\mathrm{C}}$ of the coordinating cation alone. The spatial components $i_{\mathrm{v}}^{\mathrm{C}}$ or $i_{\mathrm{s} \text {.a. }}^{\mathrm{C}}$ are used to calculate $\dddot{\hbar}$ but it appears to be unimportant which is used as they both change proportionally with one another between different cations. However, $i_{\mathrm{v}}^{\mathrm{C}}$ gives a slightly better fit with a higher $R^{2}$ value of 0.952 (given the larger number of independent reports using different phases, systems and detection equipment spanning over $>50$ years this is a fairly good fit) compared with 0.942 using $i_{\text {s.a. }}^{\mathrm{C}}$ (Fig. S1, ESI $\dagger$ ). Plotting on a logarithmic scale shows this correlation more clearly (Fig. 3). All reports of $\mathrm{LiO}_{2}$ except for one ${ }^{36}$ were excluded, this is discussed in Section 3.6.

When detecting the $\nu_{\mathrm{O}-\mathrm{O}}$ of $\mathrm{O}_{2}{ }^{\bullet-}$, the derived equation for the line of best-fit (eqn (5)) from Fig. 3 can be used to help estimate its ionic character and the coordination strength of the environment in terms of $\mathcal{W}_{i_{\mathrm{v}}}^{\mathrm{C}}$. With this knowledge, $\mathrm{O}_{2}^{\bullet-}$ can be used as a diagnostic molecule to probe ion and even electrolyte interactions spectroscopically in environments where

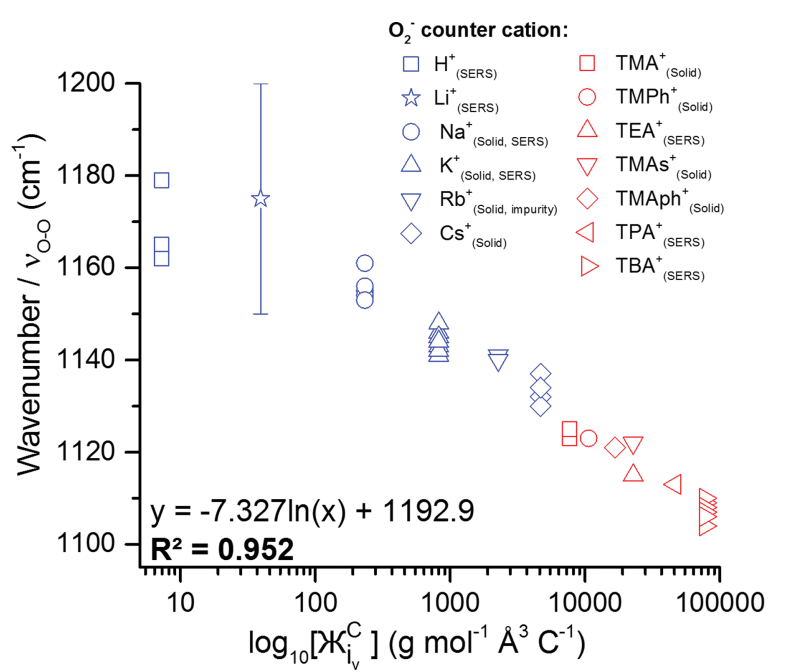

Fig. $3 \nu_{\mathrm{O}-\mathrm{O}}$ Raman band positions for $\left[\mathrm{C}^{+} \ldots \mathrm{O}_{2}{ }^{-}\right]$complexes plotted versus the calculated $\log _{10} \Psi_{i_{\mathrm{v}}}^{\mathrm{C}}$ (see Table S1, ESI $\dagger$ ) of the coordinating cation. Empirically derived equations for the lines of best fit and $R^{2}$ values for the fits are shown in bottom left-hand corner. $\nVdash^{\mathrm{C}}$ was calculated using $i_{v}^{C}$ which provides a better fit than using $i_{\text {s.a. }}^{C}, i_{v}^{C}$ and $i_{\text {s.a. }}^{C}$. Ionic volumes and surface areas were calculated in Spartan 15 using a CPK model for single atom cations (blue) and DFT (B3LYP, 6-31G*) for molecular cations (red). A single reference ${ }^{36}$ of $\mathrm{LiO}_{2}\left(\nu_{\mathrm{O}-\mathrm{O}}\right)$ has been considered due to the wide variation in wavenumber position reported, as discussed within the main text.

the coordination strength is unknown (e.g. novel electrolytes). This relationship between $\nu_{\mathrm{O}-\mathrm{O}}$ and $\mathcal{K}_{i_{\mathrm{v}}}^{\mathrm{C}}$ in Fig. 3 was found to hold in most cases. However, it can be manipulated by changing the symmetry, steric hindrance and charge of the coordinating cation, as well as the solvents Gutmann acceptor/donor numbers $^{63}$ and the potential at an electrode surface, where $\mathrm{O}_{2}{ }^{\bullet-}$ is generated electrochemically (to be discussed elsewhere).

$$
\nu_{\mathrm{O}-\mathrm{O}}=-7.327 \log \left[\varlimsup_{i_{\mathrm{v}}}^{\mathrm{C}}\right]+1192.9
$$

Considering these findings, hydrogen superoxide $\left(\mathrm{HO}_{2}\right)$ has a high $\nu_{\mathrm{O}-\mathrm{O}}$ value $\left(>1165 \mathrm{~cm}^{-1}\right)^{26,29}$ and $\mathrm{O}_{2}{ }^{\bullet-}$ can be considered

Table 1 Table of calculated $i_{v}^{C}, i_{\text {s.a., }}^{C} \Psi_{i_{\mathrm{v}}}^{\mathrm{C}}$ and $\Psi_{i_{\text {s.a. }}}^{\mathrm{C}}$ values for some common cations and IL cations. Cations with smaller $\Psi^{\prime}$ values are expected to be stronger Lewis acids

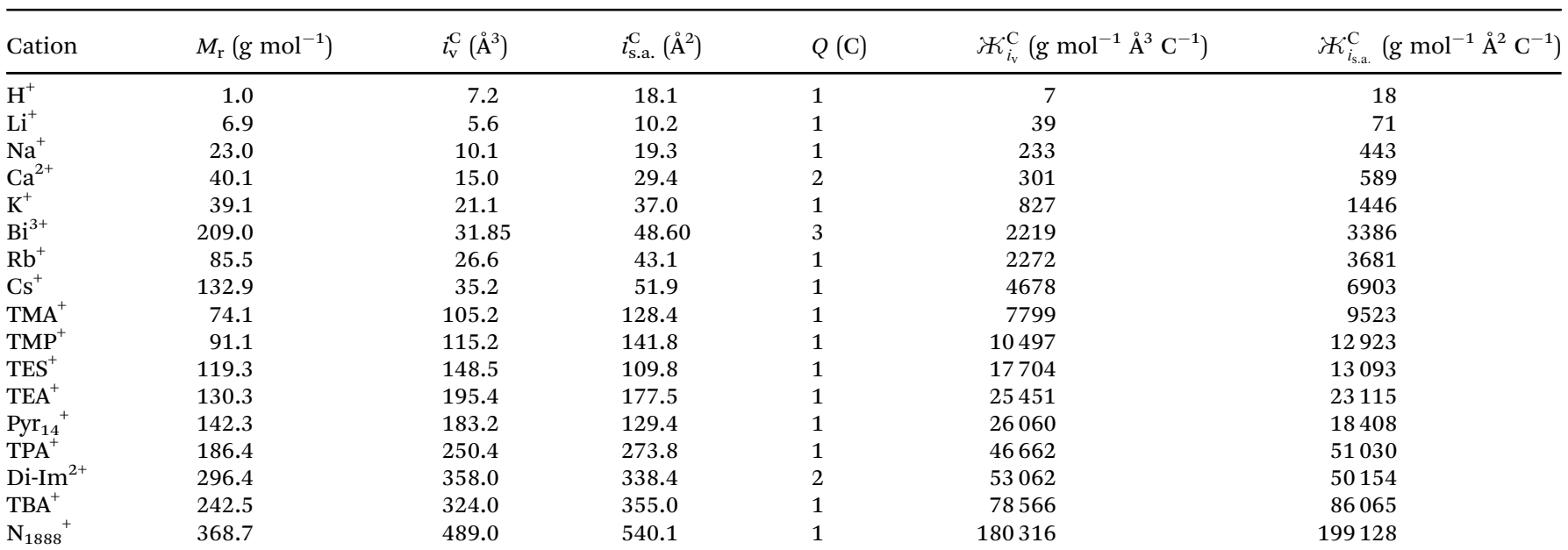




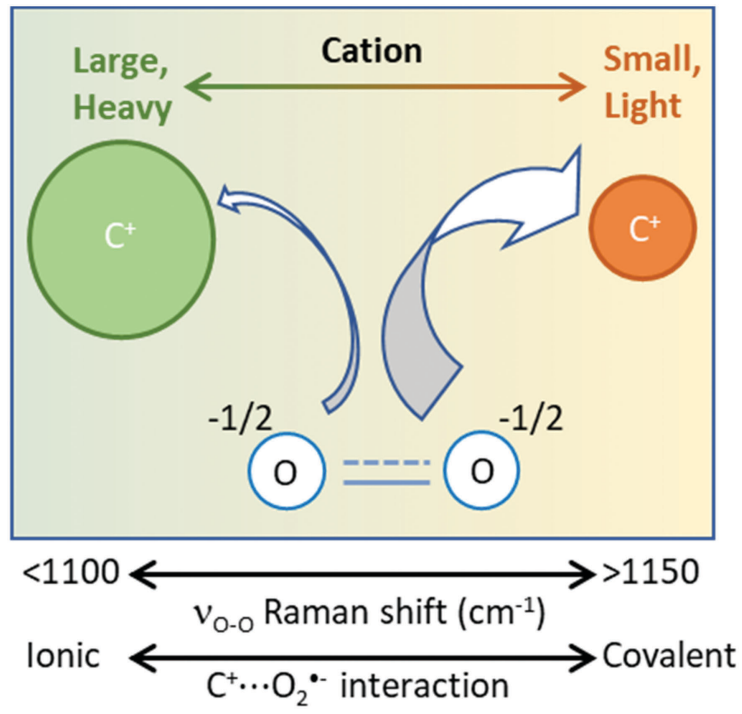

Fig. 4 Schematic depicting the strength of ion interactions in $\left[\mathrm{C}^{+} \ldots \mathrm{O}_{2}{ }^{-}\right]$ complexes. The size of the white arrows indicates the strength of the interaction between $\mathrm{O}_{2}{ }^{--}$and the coordinate-cation. Small, light cations have concentrated charge with stronger electrostatic forces of attraction and may even be able to abstract $\mathrm{O}_{2}{ }^{--}$electron density producing a covalent-like interaction, whilst the reverse is true for ions where the charge is dispersed over a large mass and area.

to have some covalent character, sharing part of its valence bonding electron with the cation. Whereas, tetrabutylammonium superoxide $\left(\mathrm{TBAO}_{2}\right)$ has a low $\nu_{\mathrm{O}-\mathrm{O}}$ value and can be considered to contain dissociated ions. Fig. 4 depicts this relationship between the cation, $\mathrm{O}_{2}{ }^{\bullet-}$ and $\nu_{\mathrm{O}-\mathrm{O}}$ schematically.

\subsection{Ionic charge dispersion of other ions}

The $\mathscr{T}$ value estimates the dispersion of a formal charge on an ion by assuming the charge is delocalised (i.e. dispersed uniformly across the volume and molecular mass of the ion). $\Psi$ is a simple value that can be calculated for any ion to approximate its coordination strength and/or propensity to interact with oppositely charged ions. Small $\dddot{\hbar}$ values indicate ions that are strong: coordinators or Lewis acid/bases, whilst large values represent weak: coordinators or Lewis acid/bases. This can be further explained in terms of hard-soft acid-base
(HSAB) theory. Hard acids interact better with hard bases and soft acids with soft bases. ${ }^{64}$ Ions with low $\mathscr{T}$ values can be consider hard Lewis acid/bases and ions with high $\varlimsup$ values can be considered soft Lewis acid/bases.

Tables 1 and 2 list calculated $\dddot{T}$ values for some common cations and anions, respectively. The $\varlimsup$ value is a clear simplification of the charge on an ion, excluding many important contributions to inter-ion interactions such as: steric hindrance, charge density, the component molecules oxidation states and

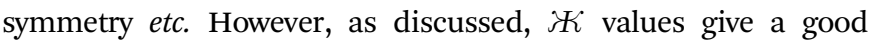
approximation for the influence of the cation on the $\nu_{\mathrm{O}-\mathrm{O}}$ of $\mathrm{O}_{2}{ }^{\bullet-}$ and are likely applicable to other systems too. Furthermore, additional quantifiable values for other ion properties (such as: symmetry etc.) could be added to refine the $\mathscr{T}$ parameter further in future. When selecting ions for their attractive strength $Æ$ parameters (and possibly $\mathscr{T}^{\mathrm{C}}: \mathscr{W}^{\mathrm{A}}$ ratios) could be used to quickly screen some of the near infinite number of ions and combinations that can be selected. Also, $Æ$ parameters give a quick and cheap starting point when designing and tailoring novel IL electrolytes or salts. This is a good starting point compared with more precise computational or experimental techniques which are expensive, time consuming and would necessarily come later after first narrowing the field of search. Based on the $\Psi_{i_{\mathrm{v}}}^{\mathrm{C}}$ value, the calculated Coulombic attractive strength of cations on anions is suggested to be similar for: $\mathrm{Na}^{+}$and $\mathrm{Ca}^{2+}\left(233\right.$ and $\left.301 \mathrm{~g} \mathrm{~mol}^{-1} \AA^{3} \mathrm{C}^{-1}\right), \mathrm{Rb}^{+}$and $\mathrm{Bi}^{3+}(2272$ and $2219 \mathrm{~g} \mathrm{~mol}^{-1} \AA^{3} \mathrm{C}^{-1}$ ) and $\mathrm{TEA}^{+}$and $\mathrm{Pyr}_{14}^{+}$(25 451 and $26060 \mathrm{~g} \mathrm{~mol}^{-1} \AA^{3} \mathrm{C}^{-1}$, respectively).

Similarly, for the $\mathcal{W}_{i_{\mathrm{v}}}^{\mathrm{A}}$ of anions, the Coulombic attractive strength of anions on cations is suggested to be similar for: $\mathrm{F}^{-}$ and $\mathrm{OH}^{-}\left(-276\right.$ and $-296 \mathrm{~g} \mathrm{~mol}^{-1} \AA^{3}$, respectively), $\mathrm{Cl}^{-}$and $\mathrm{O}_{2}{ }^{\bullet-}\left(-840\right.$ and $738 \mathrm{~g} \mathrm{~mol}^{-1} \AA^{3}$, respectively), whilst $\mathrm{I}^{-}$is comparable with dicyanamide $\left(\mathrm{DiCN}^{-}\right)$and $\mathrm{ClO}_{4}{ }^{-}(-4414$, -4295 and $-5384 \mathrm{~g} \mathrm{~mol}^{-1} \AA^{3}$, respectively).

\subsection{Dioxygen spectra and important bond parameters}

It is of great practical value to relate physical bond parameters with spectral measurements so they can be derived with ease experimentally. To that end, several efforts have been made, however, these methods remain empirical. ${ }^{65}$ Key $\mathrm{O}_{2}{ }^{x}$ bond

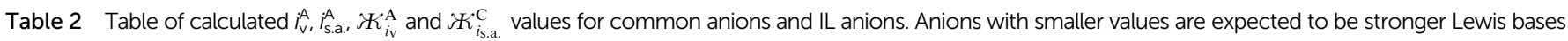

\begin{tabular}{|c|c|c|c|c|c|c|}
\hline Anion & $M_{\mathrm{r}}\left(\mathrm{g} \mathrm{mol}^{-1}\right)$ & $i_{\mathrm{v}}\left(\AA^{3}\right)$ & $i_{\mathrm{sa}}\left(\AA^{2}\right)$ & $Q(\mathrm{C})$ & $\mathscr{K}_{i_{\mathrm{v}}}^{\mathrm{A}}\left(\mathrm{g} \mathrm{mol}^{-1} \AA^{3} \mathrm{C}^{-1}\right)$ & $\mathscr{K}_{i_{\text {s.a. }}}^{\mathrm{A}}\left(\mathrm{g} \mathrm{mol}^{-1} \AA^{3} \mathrm{C}^{-1}\right)$ \\
\hline $\mathrm{O}^{2-}$ & 16.0 & 14.7 & 29.0 & 2 & -118 & -232 \\
\hline $\mathrm{F}^{-}$ & 19.0 & 14.5 & 28.8 & 1 & -276 & -547 \\
\hline $\mathrm{OH}^{-}$ & 17.0 & 17.1 & 32.8 & 1 & -291 & -558 \\
\hline $\mathrm{O}_{2}{ }^{2-}$ & 32.0 & 25.1 & 44.1 & 2 & -402 & -705 \\
\hline $\mathrm{O}_{2}^{\bullet-}$ & 32.0 & 23.1 & 40.7 & 1 & -738 & -1302 \\
\hline $\mathrm{Cl}^{-}$ & 35.5 & 23.7 & 39.9 & 1 & -840 & -1415 \\
\hline $\mathrm{Br}^{-}$ & 79.9 & 28.0 & 44.7 & 1 & -2239 & -3569 \\
\hline $\mathrm{NO}_{3}{ }^{-}$ & 62.0 & 41.2 & 61.6 & 1 & -2552 & -3817 \\
\hline $\mathrm{SO}_{4}^{2-}$ & 96.1 & 55.0 & 73.7 & 2 & -2642 & -3538 \\
\hline $\mathrm{I}^{-}$ & 126.9 & 34.8 & 51.5 & 1 & -4414 & -6539 \\
\hline $\mathrm{DiCN}^{-}$ & 66.0 & 65.0 & 88.7 & 1 & -4295 & -5859 \\
\hline $\mathrm{ClO}_{4}^{-}$ & 99.4 & 54.1 & 70.2 & 1 & -5384 & -6981 \\
\hline $\mathrm{OTf}^{-}$ & 149.1 & 83.6 & 81.4 & 1 & -12455 & -12127 \\
\hline TFSI $^{-}$ & 280.1 & 153.5 & 115.2 & 1 & -43014 & -32262 \\
\hline
\end{tabular}


Table 3 Bond parameters of various $\mathrm{O}_{2}{ }^{x}$ species and their outer $\pi^{\star}\left(2 p_{x y}\right)$ valence orbital structures are listed. Raman spectral band $\nu_{\mathrm{O}-\mathrm{O}^{x}} / \nu_{\mathrm{O}-\mathrm{O}}^{\text {peroxide }}$ ratios show good approximations with $B_{\bigcirc}$ indicating that energy changes in the bond vibration are directly proportional to the addition or removal of a valence electron. Correlating these values allows $\nu_{\mathrm{O}_{-}}$to be used to approximate the $B_{\odot}$ and other bond parameters

\begin{tabular}{|c|c|c|c|c|c|}
\hline $\mathrm{O}-\mathrm{O}$ bond parameters & $\mathrm{O}_{2}{ }^{2-}$ & $\mathrm{O}_{2}^{\bullet-}$ & $\mathrm{O}_{2}$ & $\mathrm{O}_{2}^{+}$ & Ref. \\
\hline$\pi^{*}\left(2 \mathrm{p}_{x y}\right)$ MO outer valence structure & $1 l 1 l$ & $1 \downarrow 1$ & 11 & 1 & - \\
\hline Bond length $/ B_{\mathrm{L}}(\AA)$ & 1.49 & 1.34 & 1.24 & 1.12 & 68 \\
\hline Bond enthalpy $/ B_{\mathrm{H}}\left(\mathrm{kJ} \mathrm{mol}^{-1}\right)$ & 149 & 360 & 498 & 644 & 68 \\
\hline Bond force constant $/ B_{\mathrm{k}}\left(\right.$ mdyn $\left.\AA^{-1}\right)$ & 2.56 & 6.18 & 11.4 & 16.3 & 8,13 and 69 \\
\hline$\nu_{\mathrm{O}-\mathrm{O}}{ }^{x}$ & $743^{\mathrm{a}}$ & $1108^{b}$ & $1556^{\mathrm{c}}$ & $1876^{\mathrm{c}}$ & $9,15,53,58$ and $70-72$ \\
\hline Bond order $/ B_{\mathrm{O}}$ & 1 & 1.5 & 2 & 2.5 & - \\
\hline$\nu_{\mathrm{O}-\mathrm{O}} x / \nu_{\mathrm{O}-\mathrm{O}}^{\text {peroxide }}$ & 1 & 1.49 & 2.10 & 2.53 & - \\
\hline
\end{tabular}

Where: $\mathrm{a}=\nu_{\mathrm{O}-\mathrm{O}}$ of (weakly coordinated) $\mathrm{Cs}_{2} \mathrm{O}_{2}$ salt, $\mathrm{b}=\nu_{\mathrm{O}-\mathrm{O}}$ of $\mathrm{TBAO}_{2}$ generated in dimethyl sulfoxide (DMSO), $\mathrm{c}=\nu_{\mathrm{O}-\mathrm{O}}$ of gaseous dioxides.

parameters such as the bond order $\left(B_{\mathrm{O}}\right)$, bond dissociation enthalpy $\left(B_{\mathrm{H}}\right)$, bond force constant $\left(B_{\mathrm{k}}\right)$ and bond length $\left(B_{\mathrm{L}}\right)$ require various experimental procedures to derive, like X-ray crystallography (XRC). Bond parameter values for most $\mathrm{O}_{2}{ }^{x}$ species exist and can be correlated well with empirically measured $\nu_{\mathrm{O}-\mathrm{O}}$ values. Table 3 lists these bond parameters for different $\mathrm{O}_{2}{ }^{x}$ species. Correlating these $\mathrm{O}-\mathrm{O}$ bond parameters allows for variations in each bond parameter to be estimated by only measuring the $\nu_{\mathrm{O}-\mathrm{O}}$ of the $\mathrm{O}_{2}{ }^{x}$ species.

Considering the relationship between $\nu_{\mathrm{O}-\mathrm{O}}$ and the coordinating cation discussed in the previous section: $\left[\mathrm{C}^{+} \cdots \mathrm{O}_{2}{ }^{--}\right]$ complexes with strong coordinating cations can be considered to have partial-covalent character, i.e. the coordinating cation abstracts some amount of the $\mathrm{O}_{2}{ }^{\cdot-}$ valence bond electron density. This bond electron density abstraction interaction between the dioxide ion and its coordinator is here on referred to as secondary covalency. For different $\mathrm{O}_{2}{ }^{--}$species, the amount of electron density abstracted by the cation can be estimated by considering the $B_{\mathrm{O}}$ of other $\mathrm{O}_{2}{ }^{x}$ species. A change of 0.5 in the $B_{\mathrm{O}}$ corresponds to an electron being added or removed from the $\mathrm{O}-\mathrm{O}$ bond. By assuming the $B_{\mathrm{O}}$ is variable, then a change of 0.25 indicates a valence bond electron being shared with the coordination environment, discussed later. A fully dissociated $\mathrm{O}_{2}{ }^{2-}$ species has a $B_{\mathrm{O}}$ of 1 and there is an approximately linear relationship between the $B_{\mathrm{O}}$ and the bond force constant. ${ }^{66,67}$ As the bond force constant dictates the wavenumber of the $\nu_{\mathrm{O}-\mathrm{O}}$, therefore, calculating the ratio between the $\nu_{\mathrm{O}-\mathrm{O}}$ of various $\mathrm{O}_{2}{ }^{x}$ species and the $\nu_{\mathrm{O}-\mathrm{O}}$ of $\mathrm{O}_{2}{ }^{2-}\left(\nu_{\mathrm{O}-\mathrm{O}}{ }^{x} / \nu_{\mathrm{O}-\mathrm{O}}^{\text {peroxide }}\right)$ generates values that match well with the actual $\mathrm{O}-\mathrm{O} B_{\mathrm{O}}$ (Table 3) as observed by Livneh $e t a l^{9}$

Due to their high $\mathcal{W}_{i_{\mathrm{v}}}^{\mathrm{C}}$ values; $\mathrm{Cs}^{+}\left(4678 \mathrm{~g} \mathrm{~mol}^{-1} \AA^{3} \mathrm{C}^{-1}\right)$ and TBA $^{+}\left(78656 \mathrm{~g} \mathrm{~mol}^{-1} \AA^{3} \mathrm{C}^{-1}\right.$ ) are weak coordinating cations. Therefore, the $B_{\mathrm{O}}$ of $\mathrm{Cs}_{2} \mathrm{O}_{2}{ }^{9,15,53}$ and $\left[\mathrm{TBA}^{+} \ldots \mathrm{O}_{2}{ }^{\bullet-}\right]^{25,26}$ can be assumed to be 1 and 1.5 and their Raman spectra used as $\nu_{\mathrm{O}-\mathrm{O}}$ values for dissociated $\mathrm{O}_{2}{ }^{2-}$ and $\mathrm{O}_{2}{ }^{--}$, respectively. In reality, both oxides will have some slight covalent character, however, even without considering this, and also the contributions from anharmonicity in the $\mathrm{O}-\mathrm{O}$ bond vibration (which are relatively small and decrease in magnitude from $\mathrm{O}_{2}{ }^{+}$to $\mathrm{O}_{2}{ }^{2-}$ ), ${ }^{9}$ we see good agreement between the $B_{\mathrm{O}}$ and $\nu_{\mathrm{O}-\mathrm{O}}{ }^{x} / \nu_{\mathrm{O}-\mathrm{O}}^{\text {peroxide }}$ ratios in Table 3. Fitting bond parameters in Fig. 5 with respect to known $B_{\mathrm{O}}$ values allows simple fits (eqn (6) and Table S2, ESI $\dagger$ ) for estimating $\mathrm{O}_{2}{ }^{x}$ bond parameters to be derived. The trends are approximately linear, however, more accurate cubic fits where used. Therefore, provided the $\nu_{\mathrm{O}-\mathrm{O}}$ of a $\mathrm{O}_{2}{ }^{x}$ is know, it is suggested that all other bond parameters can be estimated.

$$
y=\mathrm{A} x^{3}+\mathrm{B} x^{2}+\mathrm{C} x+\mathrm{D}
$$

where $B_{\mathrm{O}}=$ bond order, $n=$ number of bonding electrons, $n^{*}=$ number of antibonding electrons.

To further qualify that the relationship between the $\nu_{\mathrm{O}-\mathrm{O}}$ of $\mathrm{O}_{2}{ }^{x}$ and its bond parameters are approximately linear/cubic: it would be expected that a $\mathrm{O}_{2}{ }^{x}$ species with secondary covalency (i.e. a $\mathrm{O}_{2}{ }^{x}$ species with the outer valence electron partially shared with its coordinating environment) would have a $B_{\mathrm{O}}$ between that of two fully dissociated $\mathrm{O}_{2}{ }^{x}$ species. For example, a $\mathrm{O}_{2}{ }^{x}$ species with a $B_{\mathrm{O}}$ between that of $\mathrm{O}_{2}{ }^{2-}\left(B_{\mathrm{O}}=1\right)$ and $\mathrm{O}_{2}{ }^{\bullet-}$ $\left(B_{\mathrm{O}}=1.5\right)$ would be expected to have a $B_{\mathrm{O}}$ of $\sim 1.25$, and would have a $\pi^{*}(2 \mathrm{p})$ orbital structure between that of a $\mathrm{O}_{2}{ }^{2-}$, [1 $\mathrm{l} 1 \mathrm{l}$ ], and $\mathrm{O}_{2}{ }^{--}$, [1 1 1], species. Thus, such a $\mathrm{O}_{2}{ }^{x}$ species would have a
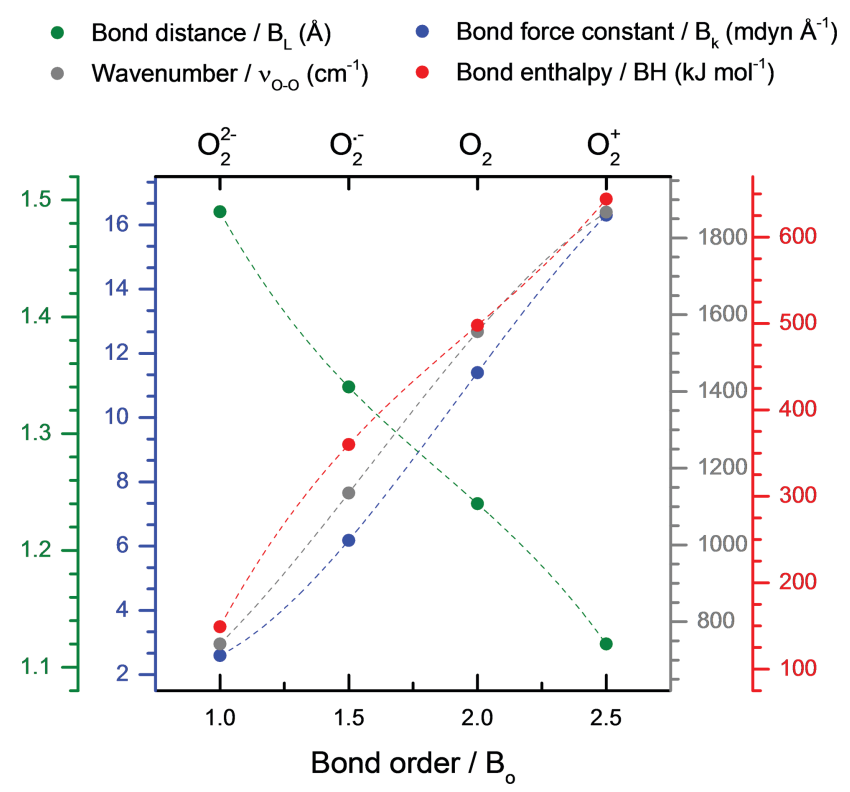

Fig. 5 Fitted plots of $\mathrm{O}_{2}{ }^{x}$ bond parameters from Table 3 against the $B_{\mathrm{O}}$. Colour-coordinated axis labels are shown above the graph. Cubic lines of best fits are shown by dashed lines. Fit values shown in Table 4. 
detectable bond vibration and $\nu_{\mathrm{O}-\mathrm{O}}$ band somewhere between that of a strongly coordinated $\mathrm{O}_{2}{ }^{2-}$ species $\left(e . g . \mathrm{H}_{2} \mathrm{O}_{2}: 875 \mathrm{~cm}^{-1}\right)$ and a fully-dissociated $\mathrm{O}_{2}^{\bullet-}\left(\right.$ e.g. a $\left.\left[\mathrm{TBA}^{+} \cdots \mathrm{O}_{2}^{\bullet-}\right]: \sim 1108 \mathrm{~cm}^{-1}\right)$ species. ${ }^{67}$ Therefore, $\nu_{\mathrm{O}-\mathrm{O}}$ values between those of these two species can be considered to have secondary covalent character, with valence bond electron density being shared by the $\mathrm{O}_{2}{ }^{x}$ anion with its coordinating environment. Such a $\mathrm{O}_{2}{ }^{x}$ species would be expected to have a partial dipole moment induced by the coordination interaction and the $\nu_{\mathrm{O}-\mathrm{O}}$ band would be both Raman and IR active. ${ }^{73}$ Searching the literature this was indeed found to be the case for the $\nu_{\mathrm{O}-\mathrm{O}}$ of organic peroxyls, ${ }^{74,75}$ transition metal superoxo-complexes, ${ }^{6,76,77}$ and metalloenzymes, ${ }^{78}$ which all had Raman and/or IR values reported in the range between $875-1108 \mathrm{~cm}^{-1}$. Also, this trend in $\nu_{\mathrm{O}-\mathrm{O}}$ would be expected to be the same for $\mathrm{O}_{2}{ }^{x}$ species with superoxo-oxyl and oxo-dioxygenyl character which was also observed to be the case and is discussed in detail below. To clarify language, the $\mathrm{O}_{2}{ }^{x}$ valence electron is assumed to be partially shared with the coordinating species and:

- Peroxo-superoxyl refers to a coordinated $\mathrm{O}_{2}{ }^{x}$ species with a $\pi^{*}(2 \mathrm{p})$ valence orbital structure between [1l $\left.1 \mathrm{l}\right]-\left[\begin{array}{ll}1 l & 1]\end{array}\right]$, a $B_{\mathrm{O}}$ between 1-1.5 and a $\nu_{\mathrm{O}-\mathrm{O}}$ value between $875-1108 \mathrm{~cm}^{-1}$.

- Superoxo-oxyl refers to a coordinated $\mathrm{O}_{2}{ }^{x}$ species with a $\pi^{*}(2 \mathrm{p})$ valence orbital structure between [1l 1]-[1 1], a $B_{\mathrm{O}}$ between 1.5-2 and a $\nu_{\mathrm{O}-\mathrm{O}}$ value between $1179-1552 \mathrm{~cm}^{-1}$.

- Oxo-dioxygenyl refers to a coordinated $\mathrm{O}_{2}{ }^{x}$ species with a $\pi^{*}(2 \mathrm{p})$ valence orbital between [1 1]-[1], a $B_{\mathrm{O}}$ between $2-2.5$ and a $\nu_{\mathrm{O}-\mathrm{O}}$ value between $1552-1825 \mathrm{~cm}^{-1}$.

\subsection{Secondary covalent bonding}

All the above discussed $\nu_{\mathrm{O}-\mathrm{O}}$ spectral bands for various $\mathrm{O}_{2}{ }^{x}$ species $(>200)$ have had their estimated bond properties calculated (using eqn (6) and Table 4) and have been plotted against their calculated $B_{\mathrm{O}}$ (Fig. 6). $\mathrm{O}_{2}{ }^{x}$ species with $B_{\mathrm{O}}$ values divisible by 0.5 can be considered ionic or neutral whilst those with $B_{\mathrm{O}}$ values in-between can be considered to have some amount of electron donation occurring between $\mathrm{O}_{2}{ }^{x}$ and its coordinating environment, i.e. secondary covalent bonding. Therefore, the $B_{\mathrm{O}}$ is assumed to be on a spectrum and to vary depending on how strongly coordinated the $\mathrm{O}_{2}{ }^{x}$ diatom is (and therefore, how much of its valence electron it shares).

Experimental data on $\mathrm{O}-\mathrm{O}$ bond parameters have been reported throughout the scientific literature for different $\mathrm{O}_{2}{ }^{x}$ complexes. XRC or neutron diffraction techniques have been used to measure the $B_{\mathrm{L}}$ of many species, therefore, the estimated $B_{\mathrm{O}}$ and $B_{\mathrm{L}}$ values calculated from the $\nu_{\mathrm{O}-\mathrm{O}}$ value can be crosscompared with experimental results to gauge their accuracy. Where the information was available for some of these

Table 4 Cubic fit constants from Fig. 5 and eqn (6). In principle, all $\mathrm{O}_{2}{ }^{x}$ parameters can be estimated by simply measuring $\nu_{\mathrm{O}-\mathrm{O}}$

\begin{tabular}{llllll}
\hline$x$ & $y$ & $A$ & $B$ & $C$ & $D$ \\
\hline$B_{\mathrm{O}}$ & $\nu_{\mathrm{O}-\mathrm{O}}$ & 592 & -550 & 884 & -184 \\
$B_{\mathrm{O}}$ & 1 & -0.0933 & 0.52 & -1.157 & 2.22 \\
$B_{\mathrm{O}}$ & $\mathrm{k}$ & -2.607 & 15 & -17.948 & 8.15 \\
$B_{\mathrm{O}}$ & $\mathrm{H}$ & 108 & -632 & 1489 & -816
\end{tabular}
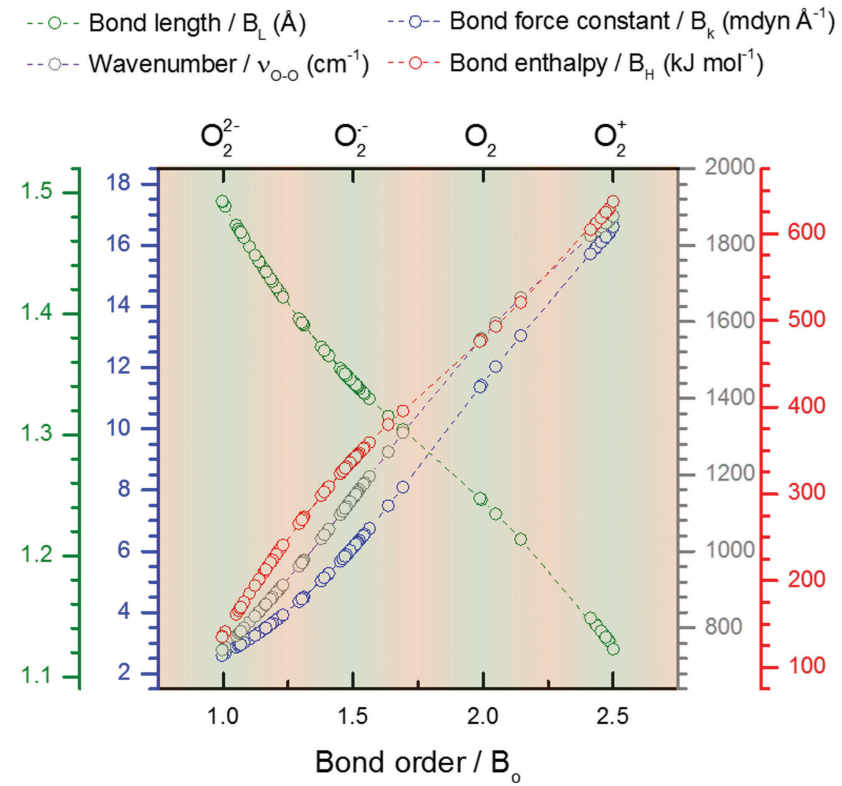

Fig. 6 Fitted plots of estimated bond parameters for various $\mathrm{O}_{2}{ }^{x}$ species calculated from the $\nu_{\mathrm{O}-\mathrm{O}}$ values reported in the literature (see Table S2 for values, ESI $\dagger$ ). Light green shaded regions signify $\mathrm{O}_{2}{ }^{x}$ species that are ionic or neutral with valence bond electrons concentrated in the $\pi_{2 p_{x, y}}{ }^{*}$ orbitals. Light orange regions signify $\mathrm{O}_{2}{ }^{x}$ species with secondary covalent interactions with the coordinate environment and where the outermost valence electron is shared with the coordinator. Colour coordinated axis labels are shown above the graph.

cross-comparisons are listed in Table S2 $(\mathrm{ESI} \dagger)$ with the difference between the measured and calculated $B_{\mathrm{L}}$ values shown as a percentage (the literature is exhaustive and largely disorganised, i.e. individual bond parameters and $\nu_{\mathrm{O}-\mathrm{O}}$ values tend to be reported in different chemical, crystallographic, spectroscopic journals, and could warrant further compilation in future). Overall, the experimentally reported $B_{\mathrm{L}}$ and the estimated $B_{\mathrm{L}}$ values match well (generally $<4 \%$ difference), supporting the correlation well. This relationship is useful for analysing $\mathrm{O}-\mathrm{O}$ properties from experimental $\nu_{\mathrm{O}-\mathrm{O}}$ results.

$$
\% \mathrm{e}^{-} \text {donation }=\frac{\left(B_{\mathrm{O}, \mathrm{c}}-B_{\mathrm{O}, \mathrm{i}}\right)}{0.25} \times 100
$$

where: $B_{\mathrm{O}, \mathrm{c}}=$ calculated bond order, $B_{\mathrm{O}, \mathrm{i}}=$ nearest $B_{\mathrm{O}}$ to the $B_{\mathrm{O}, \mathrm{c}}$ devisable by 0.5 (if the nearest bond order is less than $B_{\mathrm{O}, \mathrm{c}}$ then the species is covalent in the opposite direction). A change in bond order of 0.5 is equivalent to adding/removing an electron from $\mathrm{O}_{2}{ }^{x}$. A change in bond order of 0.25 is equivalent to adding/removing $1 / 2$ an electron (i.e. secondary covalent bond). An electron donation value of $100 \%$ indicates half the $\mathrm{O}_{2}{ }^{x}$ valence electron is being shared with the coordinate environment, i.e. a fully covalent interaction.

Considering the change in the estimated $B_{\mathrm{O}}$ value of $\mathrm{O}_{2}{ }^{x}$ species (calculated using the measured $\nu_{\mathrm{O}-\mathrm{O}}$ values) between strong and weak coordination, the secondary covalent character (i.e. amount of electron donation/abstraction between $\mathrm{O}_{2}{ }^{x}$ and its coordinating environment) can be roughly estimated (eqn (7)). This is another useful, low-cost, method for estimating the 
interaction between a $\mathrm{O}_{2}{ }^{x}$ species and its environment based solely on its experimental $\nu_{\mathrm{O}-\mathrm{O}}$ bond vibration (see examples below). Thus, a value for the amount of electron donation/ abstraction for a $\mathrm{O}_{2}{ }^{x}$ can be teased out of the $\nu_{\mathrm{O}-\mathrm{O}}$ literature. One side note, these values are not suggested to be precise; as contributions from anharmonicity are excluded etc., rather they are useful tools for quickly calculating approximate values for $\mathrm{O}_{2}{ }^{x}$ bond parameters, which confirm and enhance the understanding of its vibrational spectra. This is particularly useful for helping to understand dynamic systems that are in flux such as at an electrode surface where countless thermodynamic, kinetic and charge transfer processes are occurring simultaneously, allowing for a general understanding of reaction processes to be rationalised with respect to $\mathrm{O}_{2}{ }^{x}$ in terms of its $\nu_{\mathrm{O}-\mathrm{O}}$. This also enables $\mathrm{O}_{2}{ }^{x}$ species to be used as diagnostic molecules to probe the coordination strength of its environment by measuring the generated $\nu_{\mathrm{O}-\mathrm{O}}$ band.

Some examples calculations are given: $\mathrm{NaO}_{2}\left(1156 \mathrm{~cm}^{-1}\right)$, TBAO $_{2}\left(\sim 1108 \mathrm{~cm}^{-1}\right)$, Cu:O ${ }_{2}$ complex A $\left(1033 \mathrm{~cm}^{-1}\right),{ }^{6}$ have calculated $B_{\mathrm{O}}$ values of $1.549,1.5$, and 1.409 and electron donation values of $19.5,0$ and $-36.4 \%$, respectively. Values greater than $\pm 50 \%$ can be considered to have significant secondary covalent character. In $\mathrm{NaO}_{2}, \mathrm{Na}^{+}$can be thought of as abstracting $\sim 20 \%$ of an electron from the outer electron bond density of $\mathrm{O}_{2}{ }^{\bullet-}$, which has slight oxygen character, relative to $\mathrm{TBAO}_{2}$. While in $\mathrm{Cu}: \mathrm{O}_{2}$ complex A, the Cu-centred ligand can be thought of as donating $\sim 36 \%$ of an electron to $\mathrm{O}_{2}{ }^{--}$giving it slight peroxide character, relative to $\mathrm{TBAO}_{2}$.

Therefore:

$\% \mathrm{e}^{-}$donation to $\mathrm{Na}^{+}=\left(\frac{(1.549-1.5)}{0.25}\right) \times 100=19.5 \% \quad\left(\mathrm{NaO}_{2}\right)$

$\% \mathrm{e}^{-}$donation to $\mathrm{TBA}^{+}=\left(\frac{(1.5-1.5)}{0.25}\right) \times 100=0 \% \quad\left(\mathrm{TBAO}_{2}\right)$

$$
\begin{aligned}
\% \mathrm{e}^{-} \text {donation to } \mathrm{Cu} \text { complex } \mathrm{A} & =\left(\frac{(1.409-1.5)}{0.25}\right) \times 100 \\
& =-36.4 \% \quad\left(\mathrm{Cu}: \mathrm{O}_{2} \mathrm{~A}\right)
\end{aligned}
$$

It should be emphasised this method is not meant to be precise, rather to be used as a tool for approximating $\mathrm{O}-\mathrm{O}$ bond properties, at a glance, using empirically derived $\nu_{\mathrm{O}-\mathrm{O}}$ values for $\mathrm{O}_{2}{ }^{x}$ species' with complex structures or coordinate environments. This approach of deriving bond properties from spectral bond vibration values in different coordination environments could deliver comparable results for other homonuclear bonds and provide similar quick approximations, though this would require further work.

\subsection{The trouble with lithium superoxide}

Meta-analysis of reported Raman bands of $\mathrm{LiO}_{2}$ shows that it sticks out like a sore-thumb in terms of both a wide range of reported values and that these values, are in the main, fall outside the trend of all other measured superoxide species (Fig. 2 and 3). ${ }^{28}$ Raman spectral bands in the $\mathrm{O}_{2}{ }^{\bullet-}$ region $\left(1100-1200 \mathrm{~cm}^{-1}\right)$ have

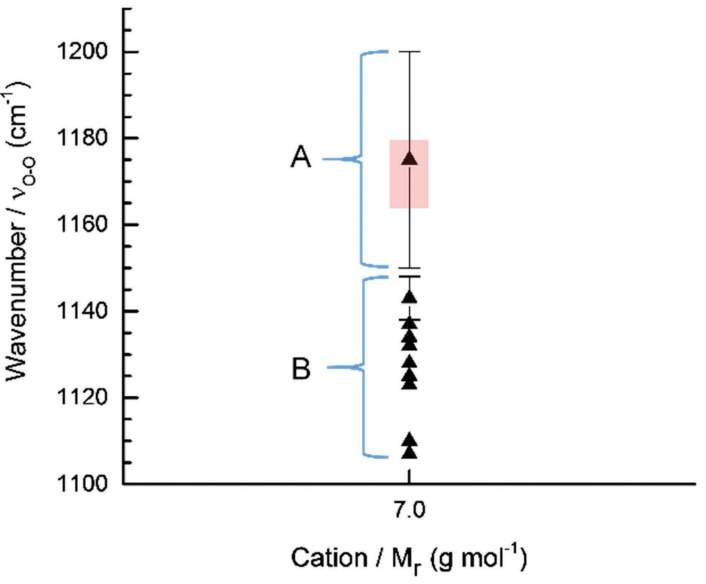

Fig. 7 Plot of $\nu_{\mathrm{O}-\mathrm{O}}$ spectral bands attributed to $\mathrm{LiO}_{2}$ in the non-aqueous $\mathrm{Li}-\mathrm{O}_{2}$ battery literature (see Table S1, ESI $\dagger$ ). The expected $\nu_{\mathrm{O}-\mathrm{O}}$ for $\mathrm{LiO}_{2}$ based on the meta-analysis would be $1167 \pm 10 \mathrm{~cm}^{-1}$, with this range highlighted by the red box.

been reported as being either chemically stable $\mathrm{LiO}_{2}$ or from polyvinylidene fluoride (PVDF) binder degradation during cycling of non-aqueous $\mathrm{Li}-\mathrm{O}_{2}$ cells (Fig. 7). ${ }^{27,38,79}$ Fundamental in situ SERS studies also report the presence of $\mathrm{LiO}_{2}$ as an intermediate produced during ORR at the roughened $\mathrm{Au}(\mathrm{rAu})$ electrode surface. ${ }^{10,11,26} \mathrm{LiO}_{2}$ has long been believed to be both thermodynamically and kinetically unstable at temperatures above $25 \mathrm{~K}^{10,50,80-85}$ and it is still unclear whether this observed intermediary species is a pure $\mathrm{LiO}_{2}$ phase or a partially electrolyte/electrode stabilised $\left[\mathrm{Li}^{+} \cdots \mathrm{O}_{2}{ }^{\bullet-}\right]$ complex. ${ }^{86,87}$ This has led to some uncertainty over whether $\mathrm{LiO}_{2}$ can exist as a stable discharge product, reaction intermediate, or at all. In light of the trend in $\nu_{\mathrm{O}-\mathrm{O}}$ of $\mathrm{O}_{2}{ }^{\bullet-}$ discussed previously, looking at the $\nu_{\mathrm{O}-\mathrm{O}}$ spectra of these reports can add to the debate.

Variation in reported bands comes down to the following: (1) $\mathrm{O}_{2}{ }^{\bullet-}$ is reacting with PVDF abstracting a proton and forming an alkene bond that causes a concomitant shift in the G-band with a serendipitously similar bond vibration to $\mathrm{O}_{2}{ }^{\bullet-}$ observed in situ. (2) $\delta^{+}$proton sites in the structure of PVDF $\left(\left[-\mathrm{CH}_{2}-\mathrm{CF}_{2}-\right]_{n}\right)$ binder are stabilising $\mathrm{O}_{2}{ }^{--}$and $\mathrm{Li}^{+}$interactions allowing a stabilised $\left[\left(\mathrm{Li}^{+}\right)_{x} \cdot \mathrm{O}_{2}{ }^{\bullet-}\right]$ complex to deposit and grow on the cathode/ binder. This could explain the accompanying distorted carbon G-band $\left(\sim 1505 \mathrm{~cm}^{-1}\right)$. (3) Due to similarities in the wavenumber

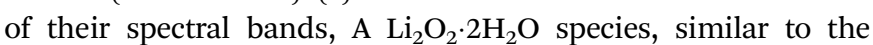
$\mathrm{Na}_{2} \mathrm{O}_{2} \cdot 2 \mathrm{H}_{2} \mathrm{O}$ species $\left(\sim 1135 \mathrm{~cm}^{-1}\right)^{48}$ observed in non-aqueous $\mathrm{Na}-\mathrm{O}_{2}$ batteries, is being formed when $\mathrm{H}_{2} \mathrm{O}$ is present in the electrolyte. (4) A thermodynamically irregular or amorphous $\mathrm{LiO}_{2}$ phase or a weakly coordinated $\left[\mathrm{Li}^{+} \cdots \mathrm{O}_{2}{ }^{\bullet-}\right]$ complex is formed. (5) A partially intercalated $\mathrm{O}_{2}{ }^{--}$species in the carbon cathode that allows $\mathrm{Li}^{+}$to bind but inhibits disproportionation to $\mathrm{Li}_{2} \mathrm{O}_{2}$ is formed. The interaction between $\mathrm{O}_{2}{ }^{\bullet-}$ and the graphitic layers could produce the observed G-band $\left(\sim 1505 \mathrm{~cm}^{-1}\right)$ shift.

From the derived $\aleph_{i_{\mathrm{v}}}^{\mathrm{C}}$ relationship, the expected $\nu_{\mathrm{O}-\mathrm{O}}$ for $\mathrm{LiO}_{2}$ was estimated to be $1167 \pm 10 \mathrm{~cm}^{-1}$, with this range shown via a red box in Fig. 7. Region (A) $\nu_{\mathrm{O}-\mathrm{O}}$ values would fit with the expected value of a $\mathrm{LiO}_{2}$ species. Only one value 
matched this and it was reported by Xia et al. who observed a broad $\nu_{\mathrm{O}-\mathrm{O}}$ band (1150-1200 $\left.\mathrm{cm}^{-1}\right)$ after discharging a non-aqueous Li- $\mathrm{O}_{2}$ battery. ${ }^{36}$ Region (B) $\nu_{\mathrm{O}-\mathrm{O}}$ values would be expected to be partially stabilised $\left[\mathrm{Li}^{+} \cdots \mathrm{O}_{2}{ }^{\bullet-}\right]$ species' or incorrectly assigned bands. Other reports of $\nu_{\mathrm{O}-\mathrm{O}}$ in a variety of different systems (Table S1, ESI $\dagger$ ) are likely surface/solution stabilised $\left[\mathrm{Li}^{+} \cdots \mathrm{O}_{2}{ }^{\bullet-}\right]$ species or possibly PVDF degradation products. ${ }^{27,42,88}$

In summary, it is suggested that many of the $\nu_{\mathrm{O}-\mathrm{O}}$ values reported as $\mathrm{LiO}_{2}$ are too low and instead environmental influences (electrolyte and electrode) are helping to stabilise a $\left[\left(\mathrm{Li}^{+}\right)_{x} \cdot \mathrm{O}_{2}{ }^{\bullet-}\right]$ complex (where $x<1$ ). Current evidence suggests; that for species generated on cathodes with PVDF binder (1) is the most probable cause of these reported ' $\nu_{\mathrm{O}-\mathrm{O}}$ ' spectral bands. However, (2) and (5) are other possibilities, but again are not a pure $\mathrm{LiO}_{2}$ product. In addition, during in situ spectroelectrochemical investigations of the interface partially electrolyte stabilised $\left[\mathrm{Li}^{+} \ldots \mathrm{O}_{2}{ }^{\bullet-}\right]$ complexes are being detected. Though, the report by Xia et al. suggests that it may still be feasible to produce a pure $\mathrm{LiO}_{2}$ phase during discharge if the conditions are right though the presence of toroid discharge product morphologies (associated with water containing electrolytes) $)^{89,90}$ may suggest $\mathrm{HO}_{2}$ was being detected rather than $\mathrm{LiO}_{2}$.

\section{Conclusions}

Superoxide $\left(\mathrm{O}_{2}{ }^{\bullet-}\right)$ vibrational spectral bands reported in the literature were collated ( $>50$ species) and trends in their coordinating environment were observed and described. The $\dddot{\pi}$ parameter based on the mass-to-charge ratio and ionic volume of the coordinating ion was derived, which gave an excellent approximation of the collated results. The $\mathscr{T}$ parameter can be calculated with relative ease for most ions and is analogous to charge density and gives a simple low-cost method of quantifying an ions Coulombic attractive strength over oppositely charged species. It was determined that $\mathrm{O}_{2}{ }^{\bullet-}$ can be used as a diagnostic molecule to probe the coordination strength of its immediate environment, by observing its vibrational spectrum. Furthermore, dioxygen vibrational spectral bands reported in the literature were collated ( $>200$ species). The trends due to the changes in the coordinating environment were observed, where changes in the $\mathrm{O}-\mathrm{O}$ vibrational spectral band were shown to be a result of electron abstraction/donation from/into the O-O bond via a 'secondary covalent' bonding interaction between the dioxygen species and its coordinating environment. A simple cubic approximation was drawn that enabled the bond order, bond dissociation enthalpy, bond length and bond force constants to be estimated solely using experimentally measured $\mathrm{O}-\mathrm{O}$ spectral bond vibrations. For the bond length this approximation gave estimated values that matched extremely well with reported values (0.5-5\%) measured experimentally using X-ray crystallography. It was shown by estimating the bond order allowed for the level of $\mathrm{e}^{-}$abstraction by the environment (i.e. the strength of the secondary covalent interaction) can also be estimated for any dioxygen species based solely on its vibrational spectra.
Raman spectrum of $\mathrm{LiO}_{2}$ was analysed and most reported bands were found to be too low to be a pure $\mathrm{LiO}_{2}$ phase, suggesting that coordinate $\left[\mathrm{Li}^{+} \cdots \mathrm{O}_{2}^{\bullet-}\right]$ complexes or degradation products are the most likely cause of these spectral reports in the non-aqueous $\mathrm{Li}-\mathrm{O}_{2}$ battery literature.

\section{Nomenclature}

\begin{tabular}{|c|c|}
\hline $\mathrm{O}_{2}^{+}$ & Dioxygen cation \\
\hline $\mathrm{O}_{2}$ & Dioxygen \\
\hline $\mathrm{O}_{2}^{\bullet-}$ & Superoxide anion \\
\hline $\mathrm{O}_{2}{ }^{2-}$ & Peroxide anion \\
\hline ROS & Reactive oxide species \\
\hline $\mathrm{O}_{2}{ }^{x}$ & Dioxide species, where $x=-2,-1,0,+1$ \\
\hline$\nu_{\mathrm{O}-\mathrm{O}}$ & O-O symmetric stretching vibration \\
\hline$\left[\mathrm{M}^{+} \cdots \mathrm{O}_{2}^{\bullet-}\right]$ & Alkali-metal superoxide complex \\
\hline$\left[\mathrm{C}^{+} \ldots \mathrm{O}_{2}^{\bullet-}\right]$ & Cation coordinated superoxide complex \\
\hline $\mathrm{C}^{+}$ & Coordinate cation \\
\hline$M_{\mathrm{r}} Q^{-1}$ & Molecular mass-to-charge ratio \\
\hline$M_{\mathrm{r}}$ & Relative molecular mass $\left(\mathrm{mol} \mathrm{g}^{-1}\right)$ \\
\hline$\left[\left(\mathrm{Li}^{+}\right)_{x} \cdots \mathrm{O}_{2}^{\bullet-}\right]$ & Superoxide rich lithium coordinate complex \\
\hline $\mathrm{XRC}$ & X-ray crystallography \\
\hline$i_{\mathrm{v}}$ & Ionic volume \\
\hline$i_{\text {s.a. }}$ & Ionic surface area \\
\hline$B_{\mathrm{O}}$ & Bond order \\
\hline$B_{\mathrm{L}}$ & Bond length \\
\hline$B_{\mathrm{k}}$ & Bond force constant \\
\hline$B_{\mathrm{H}}$ & Bond dissociation enthalpy \\
\hline $\mathrm{C}$ & Cation \\
\hline A & Anion \\
\hline 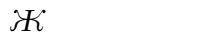 & 'Ionic charge dispersion' \\
\hline$q$ & No. of bonding electrons \\
\hline$q^{*}$ & No. of anti-bonding electrons \\
\hline$Q$ & Charge on an ion (C) \\
\hline
\end{tabular}

\section{Conflicts of interest}

There are no conflicts to declare.

\section{Acknowledgements}

We recognise funding from the joint Engineering and Physical Sciences Research Council (EPSRC) and Innovate UK grant PLAB (Practical Lithium-Air Batteries) EP/L505274/1 that enabled this work. Dr Peter Goodrich and Professor Christopher Hardacre at Queens University Belfast for the supply of ionic liquids, as well scientific discussions with Dr Sarah Ball, at Johnson Matthey, are gratefully acknowledged.

\section{Notes and references}

1 D. T. Sawyer, Oxygen chemistry, Oxford University Press, 1991. 2 M. Hayyan, M. A. Hashim and I. M. AlNashef, Superoxide Ion: Generation and Chemical Implications, Chem. Rev., 2016, 116, 3029-3085. 
3 O. Warburg, On the Origin of Cancer Cells, Science, 1956, 123, 309-314.

4 L. C. Greaves, A. K. Reeve, R. W. Taylor and D. M. Turnbull, Mitochondrial DNA and disease, J. Pathol., 2012, 226, 274-286.

5 C. R. Reczek and N. S. Chandel, The Two Faces of Reactive Oxygen Species in Cancer, Annu. Rev. Cancer Biol., 2017, 1, 79-98.

6 C. E. Elwell, N. L. Gagnon, B. D. Neisen, D. Dhar, A. D. Spaeth, G. M. Yee and W. B. Tolman, Copper-Oxygen Complexes Revisited: Structures, Spectroscopy, and Reactivity, Chem. Rev., 2017, 117, 2059-2107.

7 G. Herzberg, Molecular spectra and molecular structure, vol. 1, 1950.

8 G. W. E. Nathan Kornblum, J. Shamir, J. Binenboym, H. H. Claassen, G. W. E. Nathan Kornblum, J. Shamir, J. Binenboym and $\mathrm{H}$. H. Claassen, The vibrational frequency of the oxygen molecule $\left(\mathrm{O}_{2}^{+}\right)$cation, J. Am. Chem. Soc., 1968, 90, 6223-6224.

9 T. Livneh, A. Band and R. Tenne, Raman scattering from the peroxide ion in $\mathrm{Cs}_{2} \mathrm{O}_{2}$, J. Raman Spectrosc., 2002, 33, 675-676.

10 Z. Peng, S. A. Freunberger, L. J. Hardwick, Y. Chen, V. Giordani, F. Bardé, P. Novák, D. Graham, J.-M. Tarascon and P. G. Bruce, Oxygen reactions in a non-aqueous $\mathrm{Li}+$ electrolyte, Angew. Chem., Int. Ed., 2011, 50, 6351-6355.

11 L. Johnson, C. Li, Z. Liu, Y. Chen, S. A. Freunberger, P. C. Ashok, B. B. Praveen, K. Dholakia, J.-M. Tarascon and P. G. Bruce, The role of $\mathrm{LiO}_{2}$ solubility in $\mathrm{O}_{2}$ reduction in aprotic solvents and its consequences for $\mathrm{Li}-\mathrm{O}_{2}$ batteries, Nat. Chem., 2014, 6, 1091-1099.

12 K. M. Abraham and Z. Jiang, A polymer electrolyte-based rechargeable lithium/oxygen battery, J. Electrochem. Soc., 1996, 143, 1-5.

13 J. A. Creighton and E. R. Lippincott, Vibrational Frequency and Dissociation Energy of the Superoxide Ion, J. Chem. Phys., 1964, 40, 1779.

14 J. C. Evans, The Peroxide-ion Fundamental Frequency, J. Chem. Soc. D, 1969, 682-683.

15 J. B. Bates, M. H. Brooker and G. E. Boyd, Raman spectra of $\mathrm{O}_{2}{ }^{-}$and $\mathrm{O}_{3}{ }^{-}$ions in alkali-metal superoxides and ozonides, Chem. Phys. Lett., 1972, 16, 391-395.

16 F. J. Blunt, P. J. Hendra and J. R. Mackenzie, The laser Raman spectra of salts containing the anions $\mathrm{O}_{2}{ }^{-}$and $\mathrm{O}_{2}{ }^{2-}$, J. Chem. Soc. D, 1969, 278.

17 M. B. W. Kanzig, Molekul- und Gitterschwingungen im Natriumhyperoxid, Phys. Kondens. Mater., 1973, 112, 107-112.

18 H. H. Eysel and S. Thym, Raman Spectra of Peroxides, Z. Anorg. Allg. Chem., 1975, 411, 97-102.

19 D. A. Hatzenbuhler, Raman and Infrared Spectra of LiO2 in Oxygen Matrices, J. Chem. Phys., 1972, 56, 3398.

20 R. R. Smardzewski and L. Andrews, Raman spectra of the products of rubidium and cesium atom argon matrix reactions with oxygen molecules, J. Phys. Chem., 1973, 77, 801-804.

21 L. Andrews and R. R. Smardzewski, Argon matrix Raman spectrum of $\mathrm{LiO}_{2}$. Bonding in the $\mathrm{M}^{+} \mathrm{O}_{2}{ }^{-}$molecules and the ionic model, J. Chem. Phys., 1973, 58, 2258-2261.

22 D. T. Sawyer, T. S. Calderwood, K. Yamaguchi and C. T. Angelis, Synthesis and characterization of tetramethylammonium superoxide, Inorg. Chem., 1983, 22, 2577-2583.
23 W. Holzer, W. F. Murphy, H. J. Bernstein and J. Rolfe, Raman spectrum of $\mathrm{O}_{2}^{-}$ion in alkali halide crystals, J. Mol. Spectrosc., 1968, 26, 543-545.

24 V. S. Bryantsev, J. Uddin, V. Giordani, W. Walker, D. Addison and G. V. Chase, The Identification of Stable Solvents for Nonaqueous Rechargeable Li-Air Batteries, J. Electrochem. Soc., 2012, 160, A160-A171.

25 I. M. Aldous and L. J. Hardwick, Influence of Tetraalkylammonium Cation Chain Length on Gold and Glassy Carbon Electrode Interfaces for Alkali Metal-Oxygen Batteries, J. Phys. Chem. Lett., 2014, 5, 3924-3930.

26 T. A. Galloway and L. J. Hardwick, Utilizing in Situ Electrochemical SHINERS for Oxygen Reduction Reaction Studies in Aprotic Electrolytes, J. Phys. Chem. Lett., 2016, 7, 2119-2124.

27 J. K. Papp, J. D. Forster, C. M. Burke, H. W. Kim, A. C. Luntz, R. M. Shelby, J. J. Urban and B. D. McCloskey, Poly(vinylidene fluoride) (PVDF) Binder Degradation in $\mathrm{Li}-\mathrm{O}_{2}$ Batteries: $\mathrm{A}$ Consideration for the Characterization of Lithium Superoxide, J. Phys. Chem. Lett., 2017, 8, 1169-1174.

28 W.-J. Kwak, J.-B. Park, H.-G. Jung and Y.-K. Sun, Controversial Topics on Lithium Superoxide in $\mathrm{Li}-\mathrm{O}_{2}$ Batteries, ACS Energy Lett., 2017, 2, 2756-2760.

29 X. Li and A. A. Gewirth, Oxygen electroreduction through a superoxide intermediate on Bi-modified Au surfaces, J. Am. Chem. Soc., 2005, 127, 5252-5260.

30 I. Janik and G. N. R. Tripathi, The nature of the superoxide radical anion in water, J. Chem. Phys., 2013, 139, 014302.

$31 \mathrm{~J}$. Kim and A. A. Gewirth, Mechanism of Oxygen Electroreduction on Gold Surfaces in Basic Media, J. Phys. Chem. B, 2006, 110, 2565-2571.

32 I. Aldous, Non-aqueous Spectroelectrochemistry of Dioxygen for Alkali Metal-Oxygen Batteries, PhD thesis, University of Liverpool, 2016.

33 C. Li, O. Fontaine, S. A. Freunberger, L. Johnson, S. Grugeon, S. Laruelle, P. G. Bruce and M. Armand, Aprotic Li-O2 Battery: Influence of Complexing Agents on Oxygen Reduction in an Aprotic Solvent, J. Phys. Chem. C, 2014, 118, 3393-3401.

34 F. S. Gittleson, W. Ryu and A. D. Taylor, Operando Observation of the Gold-Electrolyte Interface in $\mathrm{Li}-\mathrm{O}_{2}$ Batteries, ACS Appl. Mater. Interfaces, 2014, 6, 19017-19025.

35 J. T. Frith, A. E. Russell, N. Garcia-Araez and J. R. Owen, An in-situ Raman study of the oxygen reduction reaction in ionic liquids, Electrochem. Commun., 2014, 46, 33-35.

36 C. Xia, M. Waletzko, L. Chen, K. Peppler, P. J. Klar and J. Janek, Evolution of $\mathrm{Li}_{2} \mathrm{O}_{2}$ Growth and Its Effect on Kinetics of $\mathrm{Li}-\mathrm{O}_{2}$ Batteries, ACS Appl. Mater. Interfaces, 2014, 6, 12083-12092.

37 D. Zhai, H.-H. Wang, J. Yang, K. C. Lau, K. Li, K. Amine and L. A. Curtiss, Disproportionation in $\mathrm{Li}_{2} \mathrm{O}_{2}$ batteries based on a large surface area carbon cathode, J. Am. Chem. Soc., 2013, 135, 15364-15372.

38 D. Zhai, H. Wang, K. C. Lau, J. Gao, P. C. Redfern, F. Kang, B. Li, E. Indacochea, U. Das, H. Sun, K. Amine and L. A. Curtiss, Raman Evidence for Late Stage Disproportionation in a Li-O $\mathrm{O}_{2}$ Battery, J. Phys. Chem. Lett., 2014, 5, 2705-2710.

39 D. Zhai, K. C. Lau, H. Wang, J. Wen, D. J. Miller, J. Lu, F. Kang, B. Li, W. Yang, J. Gao, E. Indacochea, L. A. Curtiss 
and K. Amine, Interfacial Effects on Lithium Superoxide Disproportionation in $\mathrm{Li}^{-} \mathrm{O}_{2}$ Batteries, Nano Lett., 2015, 15, 1041-1046.

40 J. Yang, D. Zhai, H.-H. Wang, K. C. Lau, J. A. Schlueter, P. Du, D. J. Myers, Y. Sun, L. A. Curtiss and K. Amine, Evidence for lithium superoxide-like species in the discharge product of a Li- $\mathrm{O}_{2}$ battery, Phys. Chem. Chem. Phys., 2013, 15, 3764-3771.

41 J. Lu, Y. Jung Lee, X. Luo, K. Chun Lau, M. Asadi, H.-H. Wang, S. Brombosz, J. Wen, D. Zhai, Z. Chen, D. J. Miller, Y. Sub Jeong, J.-B. Park, Z. Zak Fang, B. Kumar, A. SalehiKhojin, Y.-K. Sun, L. A. Curtiss and K. Amine, A lithiumoxygen battery based on lithium superoxide, Nature, 2016, 529, 377-382.

42 A. C. Luntz and B. D. McCloskey, Nonaqueous Li-Air Batteries: A Status Report, Chem. Rev., 2014, 114, 11721-11750.

43 W. H. Ryu, F. S. Gittleson, M. Schwab, T. Goh and A. D. Taylor, A mesoporous catalytic membrane architecture for lithium-oxygen battery systems, Nano Lett., 2015, 15, 434-441.

44 T. A. Galloway, L. Cabo-Fernandez, I. Aldous, F. Braga and L. Hardwick, Shell Isolated Nanoparticles for Enhanced Raman Spectroscopy Studies in Lithium-Oxygen Cells, Faraday Discuss., 2016, 205, 469-490.

45 A. Bösch and M. Känzig, Optische Eigenschaften und Elektronische Struktur von Alkali-Hyperoxide-Kristallen, Helv. Phys. Acta, 1975, 48, 743-785.

46 I. M. Aldous and L. J. Hardwick, Solvent Mediated Control of the Electrochemical Discharge Products of Non-aqueous Sodium Oxygen Electrochemistry, Angew. Chem., Int. Ed., 2016, 55, 8254.

47 P. Hartmann, C. L. Bender, M. Vračar, A. K. Dürr, A. Garsuch, J. Janek and P. Adelhelm, A rechargeable room-temperature sodium superoxide $\left(\mathrm{NaO}_{2}\right)$ battery, Nat. Mater., 2013, 12, 228-232.

48 I. Landa-Medrano, R. Pinedo, X. Bi, I. Ruiz de Larramendi, L. Lezama, J. Janek, K. Amine, J. Lu and T. Rojo, New Insights into the Instability of Discharge Products in $\mathrm{Na}-\mathrm{O}_{2}$ Batteries, ACS Appl. Mater. Interfaces, 2016, 8, 20120-20127.

49 N. Zhao and X. Guo, Cell Chemistry of Sodium-Oxygen Batteries with Various Nonaqueous Electrolytes, J. Phys. Chem. C, 2015, 119, 25319-25326.

50 N. Ortiz-Vitoriano, T. P. Batcho, D. G. Kwabi, B. Han, N. Pour, K. P. C. Yao, C. V. Thompson and Y. Shao-Horn, Rate-Dependent Nucleation and Growth of $\mathrm{NaO}_{2}$ in $\mathrm{Na}-\mathrm{O}_{2}$ Batteries, J. Phys. Chem. Lett., 2015, 6, 2636-2643.

51 I. I. Abate, L. E. Thompson, H.-C. Kim and N. B. Aetukuri, Robust $\mathrm{NaO}_{2}$ Electrochemistry in Aprotic Na-O $\mathrm{O}_{2}$ Batteries Employing Ethereal Electrolytes with a Protic Additive, J. Phys. Chem. Lett., 2016, 7, 2164-2169.

52 J. Kim, H. Park, B. Lee, W. M. Seong, H.-D. Lim, Y. Bae, H. Kim, W. K. Kim, K. H. Ryu and K. Kang, Dissolution and ionization of sodium superoxide in sodium-oxygen batteries, Nat. Commun., 2016, 7, 10670.

53 S. A. Hunter-Saphir and J. A. Creighton, Resonance Raman Scattering from the Superoxide Ion, J. Raman Spectrosc., 1998, 29, 1997-1999.
54 D. T. Sawyer, T. S. Calderwood, K. Yamaguchi and C. T. Angelis, Synthesis and Characterization of Tetramethylammonium Superoxide, Inorg. Chem., 1983, 22, 2577-2583.

$55 \mathrm{X}$. Ren and Y. Wu, A Low-Overpotential Potassium-Oxygen Battery Based on Potassium Superoxide, J. Am. Chem. Soc., 2013, 135, 2923-2926.

56 P. D. C. Dietzel, R. K. Kremer and M. Jansen, Superoxide compounds of the large pseudo-alkali-metal ions tetramethylammonium, -phosphonium, and -arsonium, Chem. Asian J., 2007, 2, 66-75.

57 J. Li and R. J. Davis, Raman spectroscopy and dioxygen adsorption on Cs-loaded zeolite catalysts for butene isomerization, J. Phys. Chem. B, 2005, 109, 7141-7148.

58 A. Band, A. Albu-Yaron, T. Livneh, H. Cohen, Y. Feldman, L. Shimon, R. Popovitz-Biro, V. Lyahovitskaya and R. Tenne, Characterization of oxides of cesium, J. Phys. Chem. B, 2004, 108, 12360-12367.

59 P. D. C. Dietzel, R. K. Kremer and M. Jansen, Tetraorganylammonium Superoxide Compounds: Close to Unperturbed Superoxide Ions in the Solid State, J. Am. Chem. Soc., 2004, 126, 4689-4696.

60 Q. Yu and S. Ye, In Situ Study of Oxygen Reduction in Dimethyl Sulfoxide (DMSO) Solution: A Fundamental Study for Development of the Lithium-Oxygen Battery, J. Phys. Chem. C, 2015, 119, 12236-12250.

61 P. Vandenabeele, Practical Raman Spectroscopy - An Introduction ALS Catalog, John Wiley \& Sons, Ltd, Chichester, UK, 2013.

62 I. M. Aldous and L. J. Hardwick, Solvent-Mediated Control of the Electrochemical Discharge Products of Non-Aqueous Sodium-Oxygen Electrochemistry, Angew. Chem., Int. Ed., 2016, 55, 8254-8257.

63 M. Schmeisser, P. Illner, R. Puchta, A. Zahl and R. van Eldik, Gutmann donor and acceptor numbers for ionic liquids, Chemistry, 2012, 18, 10969-10982.

64 W. Xu, J. Wang, F. Ding, X. Chen, E. Nasybulin, Y. Zhang and J.-G. Zhang, Lithium metal anodes for rechargeable batteries, Energy Environ. Sci., 2014, 7, 513.

65 L. Popović, D. De Waal and J. C. A. Boeyens, Correlation between Raman wavenumbers and P-O bond lengths in crystalline inorganic phosphates, J. Raman Spectrosc., 2005, 36, 2-11.

66 E. A. Robinson and M. W. Lister, A linear relation between bond orders and stretching force constants, Can. J. Chem., 1963, 41, 2988-2995.

67 C. J. Cramer, W. B. Tolman, K. H. Theopold and A. L. Rheingold, Variable character of $\mathrm{O}-\mathrm{O}$ and $\mathrm{M}-\mathrm{O}$ bonding in side-on (2) 1:1 metal complexes of $\mathrm{O}_{2}$, Proc. Natl. Acad. Sci. U. S. A., 2003, 100, 3635-3640.

68 C. E. Housecroft and E. C. Constable, Chemistry: An introduction to organic, inorganic and physical chemistry, Prentice Hall/Pearson Education, 2010.

69 P. A. Giguére and T. K. K. Srinivasan, A Raman study of $\mathrm{H}_{2} \mathrm{O}_{2}$ and $\mathrm{D}_{2} \mathrm{O}_{2}$ vapor, J. Raman Spectrosc., 1974, 2, 125-132.

70 A. Weber and E. A. McGinnis, The Raman spectrum of gaseous oxygen, J. Mol. Spectrosc., 1960, 4, 195-200. 
71 A. J. Edwards, W. E. Falconer, J. E. Griffiths, W. A. Sunder and M. J. Vasile, Syntheses and some properties of dioxygenyl fluorometallate salts, J. Chem. Soc., Dalton Trans., 1974, 1129.

72 V. V. Pushkarev, V. I. Kovalchuk and J. L. D'Itri, Probing Defect Sites on the $\mathrm{CeO}_{2}$ Surface with Dioxygen, J. Phys. Chem. B, 2004, 108, 5341-5348.

73 T. Shibahara and M. Mori, Raman and Infrared Spectra of $\mu-\mathrm{O}_{2}$ Dicobalt(III) Complexes, Bull. Chem. Soc. Jpn., 1978, 51, 1374-1379.

74 J. Oxley, J. Smith, J. Brady, F. Dubnikova, R. Kosloff, L. Zeiri and Y. Zeiri, Raman and Infrared Fingerprint Spectroscopy of Peroxide-Based Explosives, Appl. Spectrosc., 2008, 62, 906-915.

75 D. Lin-Vien, N. B. Colthup, W. G. Fateley and J. G. Grasselli, The Handbook of Infrared and Raman Characteristic Frequencies of Organic Molecules, 1991, pp. 68-72.

76 K. Qin, C. D. Incarvito, A. L. Rheingold and K. H. Theopold, A structurally characterized chromium(III) superoxide complex features 'side-on' bonding, Angew. Chem., Int. Ed., 2002, 41, 2333-2335.

77 L. M. Mirica, X. Ottenwaelder and T. D. P. Stack, Structure and Spectroscopy of Copper-Dioxygen Complexes, Chem. Rev., 2004, 104, 1013-1046.

78 E. I. Solomon, D. E. Heppner, E. M. Johnston, J. W. Ginsbach, J. Cirera, M. Qayyum, M. T. Kieber-Emmons, C. H. Kjaergaard, R. G. Hadt and L. Tian, Copper Active Sites in Biology, Chem. Rev., 2014, 114, 3659-3853.

79 J. Lu, Y. Jung Lee, X. Luo, K. Chun Lau, M. Asadi, H.-H. Wang, S. Brombosz, J. Wen, D. Zhai, Z. Chen, D. J. Miller, Y. Sub Jeong, J.-B. Park, Z. Zak Fang, B. Kumar, A. SalehiKhojin, Y.-K. Sun, L. A. Curtiss and K. Amine, A lithiumoxygen battery based on lithium superoxide (Supplementary information), Nature, 2016, 529, 1-7.

80 H. Yadegari, Q. Sun and X. Sun, Sodium-Oxygen Batteries: A Comparative Review from Chemical and Electrochemical Fundamentals to Future Perspective, Adv. Mater., 2016, 28, 7065-7093.
81 C. L. Bender, P. Hartmann, M. Vračar, P. Adelhelm and J. Janek, On the thermodynamics, the role of the carbon cathode, and the cycle life of the sodium superoxide $\left(\mathrm{NaO}_{2}\right)$ battery, Adv. Energy Mater., 2014, 4, 2-11.

82 R. H. Snow, Thermodynamic Evaluation of the Possibility of Lithium Superoxide Production, Contrails, 1965, 34.

83 V. S. Bryantsev, M. Blanco and F. Faglioni, Stability of lithium superoxide $\mathrm{LiO}_{2}$ in the gas phase: computational study of dimerization and disproportionation reactions, J. Phys. Chem. A, 2010, 114, 8165-8169.

84 N. Seriani, Ab initio thermodynamics of lithium oxides: from bulk phases to nanoparticles, Nanotechnology, 2009, 20, 1-7. 85 A. I. Belova, D. G. Kwabi, L. V. Yashina, Y. Shao-Horn and D. M. Itkis, On the Mechanism of Oxygen Reduction in Aprotic Li-Air Batteries: The Role of Carbon Electrode Surface Structure, J. Phys. Chem. C, 2017, 121, 1569-1577.

86 D. G. Kwabi, V. S. Bryantsev, T. P. Batcho, D. M. Itkis, C. V. Thompson and Y. Shao-Horn, Experimental and Computational Analysis of the Solvent-Dependent $\mathrm{O}_{2} / \mathrm{Li}^{+}-\mathrm{O}_{2}{ }^{-}$ Redox Couple: Standard Potentials, Coupling Strength, and Implications for Lithium-Oxygen Batteries, Angew. Chem., Int. Ed., 2016, 55, 3129-3134.

87 G. Yang, Y. Wang and Y. Ma, A Stable, Magnetic, and Metallic $\mathrm{Li}_{3} \mathrm{O}_{4}$ Compound as a Discharge Product in a Li-Air Battery, J. Phys. Chem. Lett., 2014, 5, 2516-2521.

88 R. Black, S. H. Oh, J.-H. Lee, T. Yim, B. Adams and L. F. Nazar, Screening for Superoxide Reactivity in $\mathrm{Li}^{-\mathrm{O}_{2}}$ Batteries: Effect on $\mathrm{Li}_{2} \mathrm{O}_{2} / \mathrm{LiOH}$ Crystallization, J. Am. Chem. Soc., 2012, 134, 2902-2905.

89 N. B. Aetukuri, B. D. McCloskey, J. M. García, L. E. Krupp, V. Viswanathan and A. C. Luntz, Solvating additives drive solution-mediated electrochemistry and enhance toroid growth in non-aqueous $\mathrm{Li}-\mathrm{O}_{2}$ batteries, Nat. Chem., 2014, 7, 50-56.

90 D. Aurbach, B. D. McCloskey, L. F. Nazar and P. G. Bruce, Advances in understanding mechanisms underpinning lithium-air batteries, Nat. Energy, 2016, 1, 16128. 